\title{
Cheating by economics and business undergraduate students: an exploratory international assessment
}

\author{
Aurora A. C. Teixeira · Maria Fátima Rocha
}

Published online: 3 September 2009

(C) Springer Science+Business Media B.V. 2009

\begin{abstract}
Today's economics and business students are expected to be our future business people and potentially the economic leaders and politicians of tomorrow. Thus, their beliefs and practices are liable to affect the definition of acceptable economics and business ethics. The empirical evaluation of the phenomenon of cheating in academia has almost exclusively focused on the US context, and non-US studies usually only cover a narrow range of countries. This paper presents a comprehensive, cross-country study on the magnitude and determinants of cheating among economics and business undergraduates, involving 7,213 students enrolled in 42 universities located in 21 countries from the American (4), European (14), Africa (2) and Oceania (1) Continents. We found that the average magnitude of copying among economics and business undergraduates is quite high (62\%) but there was significant cross-country heterogeneity. The probability of cheating is significantly lower in students enrolled in schools located in the Scandinavian, and the US and British Isles blocks when compared with their Southern European counterparts; quite surprisingly this probability is also lower for the African block. On a distinctly different level, however, students enrolled in schools in Western and especially Eastern European countries reveal statistically significant higher propensities towards committing academic fraud.
\end{abstract}

Keywords Cheating $\cdot$ University $\cdot$ Economics $\cdot$ Business $\cdot$ Countries

\section{Introduction}

Given its importance for a country's economic and political future, the education sector is expected to be particularly fair. In the book Stealing the Future: Corruption in the Classroom, the editors (Meier and Griffin 2005) underline the fact that corruption in school leads to poor quality education; they state plainly that "corruption in education is also incompatible with one of education's major aims: producing citizens that respect the law and human rights".

A. A. C. Teixeira (西)

CEF.UP, Faculdade Economia, Universidade do Porto; INESC Porto, Porto, Portugal e-mail: ateixeira@fep.up.pt

M. F. Rocha

Universidade Fernando Pessoa, Porto, Portugal 
Although the aims mentioned above are widely accepted and valued, in an article published by The New York Times (May 18, 2006), Glater described the alarming magnitude of cheating among university students and the growing concern on the part of University Deans and society in general, about the escalating pervasiveness of the phenomenon within academia and its potential (detrimental) impact on business and 'real world' ethics.

The critical issue here is that today's economics and business students are likely to be the business people of tomorrow and, as such, their beliefs and practices are liable to affect the definition of acceptable business ethics. Moreover, students' perceptions of what comprises ethical behaviour, whether accurate or not, will influence the actions they take once they enter the business world (Lawson 2004).

Students, in general, and those in Economics and Business-related areas, in particular, have grown up in a society where distinctions between right and wrong have become blurred and where unethical behaviour by high-profile leaders is somewhat expected (Kidwell 2001). Talking of the rampant trend in cheating and plagiarism at a highly regarded Thai school, a professor sadly asserted "... the students who attend this school are likely to be the movers and shakers of the future in Thailand, the people who will be in positions of power. With the idea of impunity being re-enforced to them at such a young age, can we have any hope that corruption can be eliminated, or even reduced? These future leaders of the country are getting the message that it is ok to cheat." (Stickman 2004).

Studies involving students' beliefs regarding ethical behaviour in the business world tend to be daunting. Students have been found to make consistently less ethical choices than practitioners and to possess lower ethical standards than businessmen (Hollon and Ulrich 1979; Stevens 1984; Arlow and Ulrich 1985; DeConick and Good 1989; Glenn and Van Loo 1993; Cole and Smith 1996; Lord and Melvin 1997). Wood et al. (1988) concluded that students were significantly more willing to engage in unethical behaviour than their professional counterparts. Magner (1989), reporting the results of a survey of business students at a conference on business ethics, noted that $97 \%$ of students agreed that "good ethics is good business" while $71 \%$ believed that being ethical in business could hurt them in some instances. Similarly, Glenn (1988, p. 174) reported that a majority $(54 \%)$ of the student respondents agreed with the statement that "a person in business is forced to do things that can conflict with her personal values".

Academic cheating can be (McCabe et al. 2006) as simple as cheating in test/exams, which includes overt copying from another student, the use of prohibited crib notes, helping someone else to cheat in a test, and learning in advance what the test was about from someone who took it previously, as well as cheating associated to written work, namely plagiarism. More generally, as stated by Sheard et al. (2003, p. 92) “...cheating is described in terms of a series of practices, which cover a range of areas that can be defined as illegal, unethical, immoral or against the regulations of the course or institution." The definition of a practice as cheating is, in some cases, context/institution/course dependent, as confirmed in Hrabak et al.'s (2004) study on academic misconduct among medical students. In this study academic cheating includes, besides copying in exams/test, other (less studied) illicit/fraudulent acts such as altering a class attendance list, asking a colleague to sign on their behalf or for someone else. ${ }^{1}$ On some occasions, academic cheating

\footnotetext{
${ }^{1}$ Other practices mentioned in Hrabak et al.'s (2004) study include: submitting another student's work as one's own; falsifying a teacher's signature in enrolment records; copying answers during an examination; using a crib sheet during an examination; using a mobile phone to exchange answers during an examination; finding out about test questions in advance; using private connections to arrange passing an examination; arranging with administrative personnel to be assigned to a lenient examiner; and paying an examiner to pass an examination.
} 
may involve very deliberate unethical behaviours (e.g., copying in exams) and conducts in contexts where the distinction between ethical and unethical has weakened or disappeared-according to McCuen (2008, p. 152), "most acts of plagiarism are likely acts of ignorance rather than intended acts of deception or fraud". 2

Smyth et al. (2009) (13 paired unethical situations) and Bisping et al. (2008) (31 types of misconduct) put forward rather overarching definitions of (academic) cheating. However, notwithstanding the diversity of cheating behaviours and practices within academia, regardless of the context/institution/course, copying or cheating in exams is universally accepted as illicit conduct and is, therefore, the most widely-used notion of academic cheating, as well as potentially being the most appropriate when dealing with crosscountry/cross-institutional analysis. ${ }^{3}$

Empirical assessments of the cheating phenomenon among university students have almost exclusively focused on the US context, covering usually only a few universities. Furthermore, non-US studies on the issue usually involve a rather narrow range of countries. Thus, a comparative worldwide study on the phenomenon of cheating could provide important insights into cross-country differences among university students' propensity towards illegal behaviour within academia.

Involving a broad set $(7,213)$ of undergraduate business students enrolled in Universities located in 21 countries worldwide (Argentina, Austria, Brazil, Colombia, Denmark, France, Germany, Ireland, Italy, Mozambique, New Zealand, Nigeria, Poland, Portugal, Romania, Slovenia, Spain, Sweden, Turkey, the United Kingdom, and the United States of America), this paper analyzes the magnitude and determinants of student cheating, more specifically the determinants of copying in exams by undergraduates. The countries included in the analysis cover the entire ranking of the Corruption Perception Index 2005 (TI 2006), from the country positioned in second place (New Zealand) to one of the worst ranking ones (Nigeria, 152nd in 158).

The paper is organised as follows. The next section surveys existing studies on the magnitude and determinants of cheating among university students, putting forward the study's main hypotheses. In section "Methodological issues and exploratory description of the data", the methodology applied in data collecting is described and the subsequent section (section "Evaluating the cross-country determinants of cheating propensity"), presents the econometric specification used to evaluate the phenomenon and the results. The final section concludes by discussing the main results of the study, namely the 'geopolitics' of undergraduate cheating.

\section{On the magnitude and determinants of academic cheating}

Research on academic cheating dates back to the turn of the century, with the earliest studies conducted within the fields of education and educational psychology (Hartshorne and May 1928; Campbell 1931). Since then, this body of research has been intersected with research on societal deviance, with advanced understandings in both areas as a result of this association. Research on university cheating has not, however, enjoyed as symbiotic a relationship with research on business ethics (Crown and Spiller 1998). Although university cheating does not represent unethical organizational behaviour per se, literature

\footnotetext{
2 The authors acknowledge one of the referees for such an insightful point.

${ }^{3}$ Unless explicitly mentioned, from this point on, by academic cheating/dishonesty/misconduct/fraud, we mean 'copying in exams'.
} 
focusing on the decision to engage in this behaviour may still contribute to broadening our knowledge in the domain of business ethics.

According to some studies (Sims 1993; Smyth et al. 2009), students who cheat in college are likely to become professionals who will engage in similar unethical behaviours in the workplace in the future. Earlier, Newstrom and Ruch (1976, p. 21) admitted that "it is conceivable that a student who has successfully cheated on an examination will be more likely to cheat on an expense account when he enters the world of business." These authors proceeded to question whether a student who falsified a term project or committed some type of illegal behaviour at school would also later on be capable of falsifying records of campaign contributions by his/her company.

Students generally hold the belief that people in the business world act in an unethical manner (Lawson 2004). Yet, at the same time, a substantial proportion of the students admit to having engaged in academic dishonesty. Previous researchers have noted the apparent conflict between these two phenomena: "[o]n the one hand, collegians strongly disapprove of what they perceive as the businessman's lack of integrity. On the other hand, many college students occasionally cheat on examinations. One wonders how collegians explain this apparent inconsistency. Are their temptations more severe than the businessman's? Do they regard it as less reprehensible to be unethical in academic matters than in economic? If so, why?" (Baumhart 1961, p. 19).

Outside the business area, Hrabak et al. (2004) mention that cheating in medical school may constitute a predictor of fraudulence in future medical practice. Focusing on economics students enrolled in schools located in Russia, the Netherlands, Israel and the United States, Magnus et al. (2002) show a solid correspondence between students' perceptions of cheating and social corruption. Although, as Smyth et al. (2009, p. 238) correctly assert, the link between academic cheating and cheating or illegal behaviour in the real business world is far from being unambiguously proven ("surrogates are not real and can only approximate what may occur"), Nonis and Swift (2001) found that business students who engaged in fraudulent behaviour in class were more likely to engage in fraudulent behaviour in the workplace. More recently, Crittenden et al. (2009, p. 343) contend that "corruption breed[s] corruption", demonstrating that individuals studying in countries that are extremely corrupt or corrupt are more likely to cheat at school than their counterparts from less corrupt countries.

Particularly troubling is that some educators believe that students may no longer view cheating as morally wrong (Pavela and McCabe 1993). As early as 1987, Stevens and Stevens reported a heightened concern with regard to cheating in higher education. After the American Council on Higher Education reported in 1990 that cheating at colleges was on the rise, studies began to explore the issue of cheating (Bunn et al. 1992; Kerkvliet 1994). Consistent with the work of Bunn et al. (1992) and Kerkvliet (1994) the assumption is made that cheating behaviour is related to the perceived costs and benefits of cheating. Quite possibly the decision to cheat can also vary according to certain demographic characteristics, a group of individual characteristics, as well as the educational environment.

More recent studies on cheating (e.g., Bunn et al. 1992; Kerkvliet and Sigmun 1999) are based on econometric specifications consistent with the assumption of a relation between fraudulent behaviour and the notion of costs and benefits resulting from it. Thus these studies are adaptations of Becker's (1968) crime model to academic dishonesty. ${ }^{4}$ Most of studies that examine the importance of cheating in academia in quantitative terms

\footnotetext{
${ }^{4}$ Rocha and Teixeira (2005a) account for the distinct forms of theorising illegal behaviours and adapt Becker's crime model (1968) to cheating.
} 


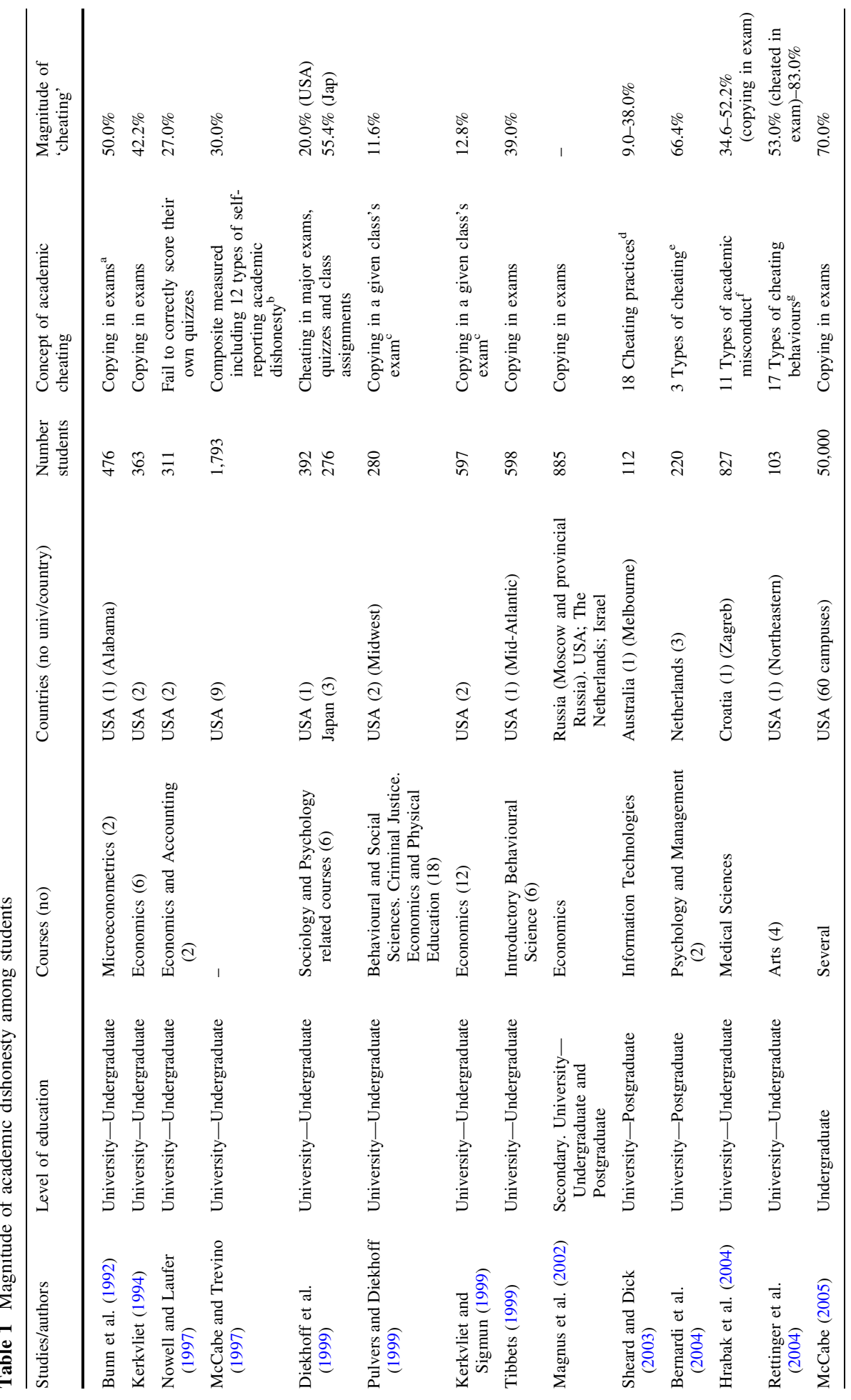




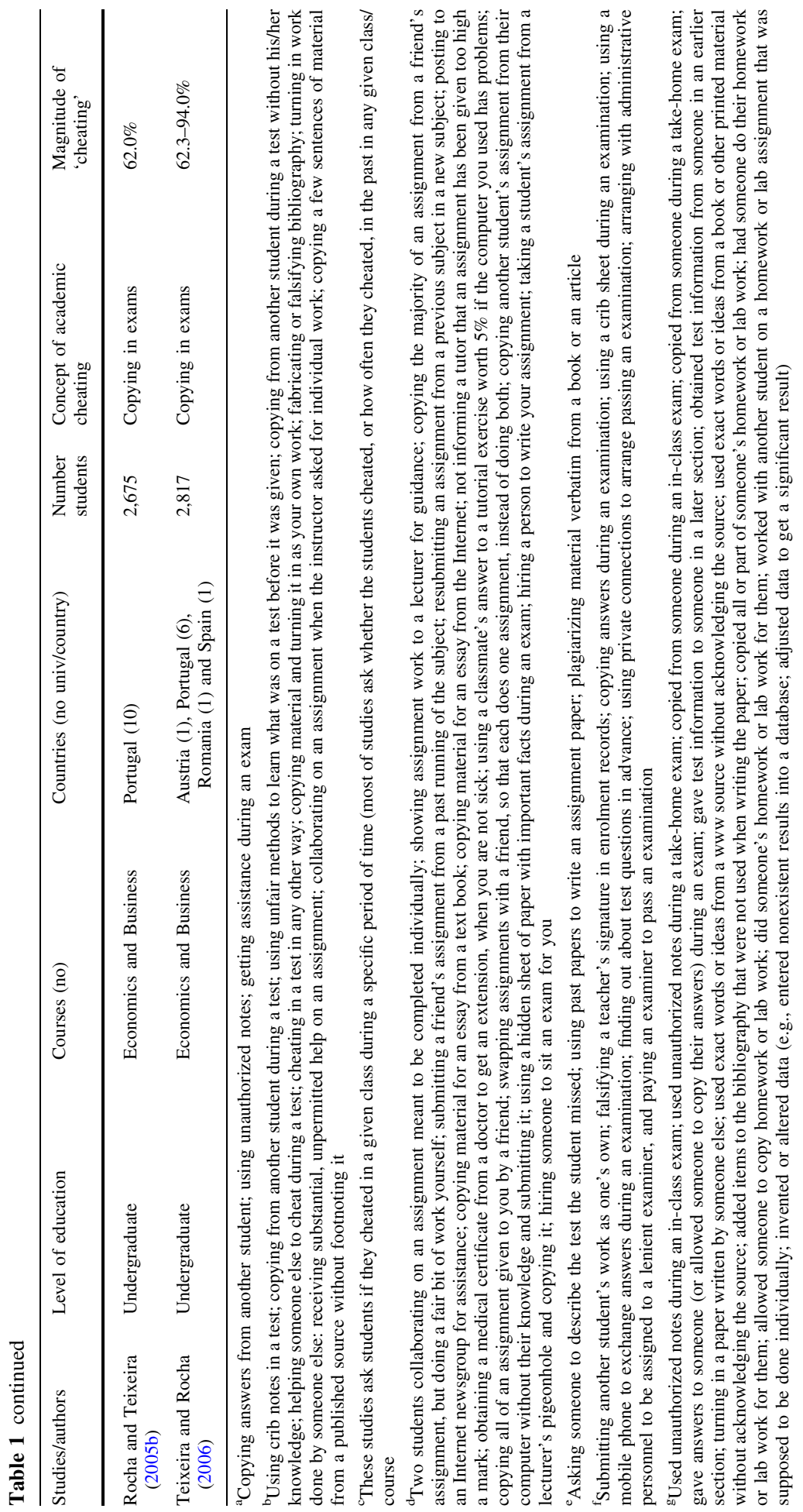


(Table 1) show that the dimension of cheating is considerable-over one-third. In one of the pioneering studies by Bunn et al. (1992), an analysis of two higher education courses in Microeconomics in Alabama (US), the authors found that half the students surveyed admitted to having copied. They also found that cheating was 'normal' among students, with $80 \%$ of them saying that they had seen a colleague copying and half of them said that they had seen a colleague being caught copying. Apart from the magnitude of the phenomenon, unlawful behaviour seems to be quite well 'interiorized' in the student community, with $28 \%$ of students admitting to knowing colleagues who copy regularly. The vast incidence of the phenomenon seems to be justified by the fact that most students (70\%) do not see copying as a serious offence (Bunn et al. 1992).

In a survey of university first-year students, Collinson (1990) found that $37 \%$ admitted to having cheated on a test in high school. Nazario (1990) cites a poll that found that $47 \%$ of the students surveyed would cheat during an exam. $78 \%$ of students surveyed at the University of Delaware acknowledged having cheated (Collinson 1990). In addition to this evidence of widespread academic misconduct, there are indications that the problem may be increasing over time (Davis et al. 1992; McCabe 2005).

In another context (two public universities in the US), and covering more courses (six Economics classes), Kerkvliet (1994) found that, in the random response questionnaire applied, $42 \%$ of the students indicated they had copied at least once in an exam. In a later study, covering 12 classes in the two universities, Kerkvliet and Sigmun (1999) estimated that an average of $12.8 \%$ of the students surveyed had copied at least once. But there was considerable disparity among the groups, ranging from $0.2 \%$ in the least 'deceitful' class to $32 \%$ in the one where cheating was more common. The authors say this disparity is due to the different measures of "intimidation" used in the various classes (number of tests per student that watch out for discipline in universities; space per student in the classroom; number of test versions used by the teacher; kind of exam).

Taking a larger population than that in Bunn et al.'s (1992) study, Nowell and Laufer (1997) looked at two higher education courses in the USA (Economics and Accounting) and concluded that the average propensity towards dishonesty was around $27 \%$.

More recently, and with reference to other scientific areas, findings by Sheard and Dick (2003) in a study on postgraduate students in Information Technology at a university in Melbourne (Australia) showed that $9 \%$ of students admitted to being involved in serious forms of cheating in exams. In other study on unlawful behaviour among students from the 2nd to the 6th year of Medicine in a Croatian university, Hrabak et al. (2004) found that 94\% admitted to having committed some kind of deceit at least once during their studies. When it came to copying answers or using 'cheat sheets' the percentages were 52.2 and $34.6 \%$, respectively. Also a considerable percentage (66.4\%) of Psychology and Management students in three Dutch universities admitted to have cheated (Bernardi et al. 2004).

In a study from the Center for Academic Integrity (CAI) conducted by McCabe (released in June, 2005), involving almost 50,000 undergraduates (covering over 60 campuses), who participated in a nationwide (USA) survey on academic integrity since the Fall of 2002, $70 \%$ of the students admitted to some form of cheating. Close to one-quarter of the participating students admitted to serious test cheating in the past year and half admitted to one or more instances of serious cheating in written assignments. Longitudinal comparisons show significant increases in serious test/examination cheating and illicit student collaboration. For example, the number of students self-reporting instances of 
prohibited collaboration at nine medium to large US state universities increased from $11 \%$ in a 1963 survey to $49 \%$ in 1993 (McCabe 2005).

Focusing on European countries, Teixeira and Rocha (2006) and Rocha and Teixeira (2005b), estimated that the magnitude of cheating (copying in exams) among undergraduate Economics and Business students was preoccupying, having reached values between $62 \%$ (Portugal) and 94\% (Romania).

In order to better understand the phenomenon of cheating, several authors (e.g., Whitley 1998) identified a host of factors associated with cheating among university students. Consistent with the organizational literature (Crown and Spiller 1998), the role individual factors play in affecting the decision to cheat has received the bulk of empirical attention.

Separate studies systematically indicate a series of determinants of academic dishonesty which may be grouped into seven major factors (Table 2)-e.g., student characteristics, factors related to the institution, variables influencing the likelihood of the phenomenon being detected and the respective cost of detection, and also causes associated with the benefits of copying (when they are not caught) and the benefits of not copying.

Grade point average (G.P.A.) and expected benefits

Bushway and Nash (1977, p. 624) reported that "the majority of studies indicate that students who are lower in school achievement may cheat more frequently." Research continues to find a significant negative relationship between cheating and G.P.A. (see Crown and Spiller (1998) for a survey). Although Bunn et al.'s (1992) results confirm this assumption many authors (Kerkvliet 1994; Nowell and Laufer 1997; Kerkvliet and Sigmun 1999) did not find the course average statistically significant. Notwithstanding, Hrabak et al. (2004) argue that the course average could be relevant in explaining attitudes to cheating. They take the view that students with a higher average have a more negative attitude to copying than those with a lower one, and further disapprove of swapping questions by phone during an exam, as well as using personal relations to pass an exam. The theoretical rationale for the difference is that the higher academic achievers have less to gain and more to lose by cheating and are, therefore, less likely to take the risk (McCabe and Trevino 1997; Nowell and Laufer 1997). In short, the higher academic achievers face a higher 'opportunity cost' or a higher 'economic opportunity loss' as result of taking a decision to cheat - a student with a high G.P.A. has more to loose if caught cheating than a student with low G.P.A., namely, as mentioned by Bunn et al. (1992), the risk of being excluded from clubs and honorary organizations. Accordingly, it is expect that G.P.A., a proxy for the 'opportunity cost of cheating', to be negatively related to cheating. To Bisping et al. (2008) G.P.A. indirectly measures the 'perceived benefits' of cheating, with less accomplished students having more to gain with that behaviour. We contend, differently from Bisping et al. (2008), that G.P.A. and 'perceived benefits' are distinct, yet related, determinants of cheating. We suggested here, linked to the cost/benefit idea (and similarly to Rocha and Teixeira 2005b), that perhaps more important than the students' course G.P.A., a critical determinant of the propensity to cheat are the students' directly perceived 'benefits', in terms of the higher grade they expect to obtain in a given exam if they copy successfully, which might be quite distinct from their course G.P.A. (students' global academic performance).

In this line, and controlling for other variables, such as G.P.A. and the country where the university is located, we aim to test the following hypotheses: 
Table 2 Factors influencing the propensity to cheat, by groups of determinants

\begin{tabular}{|c|c|c|}
\hline $\begin{array}{l}\text { Groups of } \\
\text { determinants }\end{array}$ & Determinants & Studies \\
\hline $\begin{array}{l}\text { Students } \\
\text { characteristics }\end{array}$ & $\begin{array}{l}\text { Gender } \\
\text { Average course grade (G.P.A.) } \\
\text { Consumption of alcohol } \\
\text { Academic year of studies } \\
\text { Religious preference } \\
\text { Student status } \\
\text { Have failed at least a year } \\
\text { Moral factors and kind of personality } \\
\text { Motivation and competence }\end{array}$ & $\begin{array}{l}\text { Fakouri (1972), Michaels and Miethe } \\
\text { (1989), Baird (1980), Leming (1980), } \\
\text { Haines et al. (1986), Graham et al. (1994), } \\
\text { Kerkvliet (1994), Nowell and Laufer } \\
\text { (1997), Whitley (1998), Kerkvliet and } \\
\text { Sigmun (1999), Tibbets (1999), Bernardi } \\
\text { et al. (2004), Hrabak et al. (2004), } \\
\text { Rettinger et al. (2004), Rocha and Teixeira } \\
\text { (2005b), Teixeira and Rocha (2006) }\end{array}$ \\
\hline $\begin{array}{l}\text { Factors related with } \\
\text { the education } \\
\text { institution }\end{array}$ & $\begin{array}{l}\text { Dimension and level of class } \\
\text { Category of teachers } \\
\text { Existence of an "honour code" } \\
\text { Classroom environment }\end{array}$ & $\begin{array}{l}\text { Gardner et al. (1988), May and Loyd (1993), } \\
\text { Nowell and Laufer (1997), Whitley } \\
\text { (1998), Pulvers and Diekhoff (1999), } \\
\text { Kerkvliet and Sigmun (1999), McCabe } \\
\text { et al. (2003), Rocha and Teixeira (2005b), } \\
\text { Teixeira and Rocha (2006) }\end{array}$ \\
\hline $\begin{array}{l}\text { Cost of detecting } \\
\text { academic } \\
\text { dishonesty }\end{array}$ & $\begin{array}{l}\text { Teachers' academic category } \\
\text { Existence of verbal warnings } \\
\text { regarding the resultant } \\
\text { consequences of copying in exams }\end{array}$ & $\begin{array}{l}\text { Houston (1983), Bunn et al. (1992) } \\
\text { Kerkvliet and Sigmun (1999) }\end{array}$ \\
\hline $\begin{array}{l}\text { Probability of } \\
\text { detecting copying }\end{array}$ & $\begin{array}{l}\text { Number of tests by students with the } \\
\text { goal of maintaining good } \\
\text { behaviour } \\
\text { Geographic class occupation by } \\
\text { student } \\
\text { Number of exams versions utilized } \\
\text { by instructor } \\
\text { Type of exams }\end{array}$ & Kerkvliet and Sigmun (1999) \\
\hline $\begin{array}{l}\text { Benefits of copying } \\
\text { (in the case of not } \\
\text { being caught) }\end{array}$ & $\begin{array}{l}\text { Expected grade } \\
\text { Number of "free" hours for the } \\
\text { student during the term } \\
\text { Type of Courses }\end{array}$ & $\begin{array}{l}\text { Whitley (1998), Kerkvliet and Sigmun } \\
\text { (1999), Rocha and Teixeira (2005b), } \\
\text { Teixeira and Rocha (forthcoming) }\end{array}$ \\
\hline $\begin{array}{l}\text { Benefits of not } \\
\text { copying }\end{array}$ & $\begin{array}{l}\text { Average number of weekly hours of } \\
\text { study }\end{array}$ & $\begin{array}{l}\text { Kerkvliet (1994) } \\
\text { Kerkvliet and Sigmun (1999) }\end{array}$ \\
\hline Others factors & $\begin{array}{l}\text { Students' opinion of those that copy } \\
\text { or commit other types of academic } \\
\text { dishonesty } \\
\text { Students perception in light of the } \\
\text { percentage of students that copy } \\
\text { and of rival group behaviours } \\
\text { Intensity of work ("workload") } \\
\text { Pressure not to fail } \\
\text { Type of courses } \\
\text { Country/region } \\
\text { Students' background } \\
\text { Students' origin }\end{array}$ & $\begin{array}{l}\text { Millham (1974), Houston and Ziff (1976), } \\
\text { Baird (1980), Lanza-Kaduce and Klug } \\
\text { (1986), Bunn et al. (1992), May and Loyd } \\
\text { (1993), Ward and Tittle (1993), Kerkvliet } \\
\text { (1994), McCabe and Trevino (1997), } \\
\text { Nowell and Laufer (1997), Whitley } \\
\text { (1998), Diekhoff et al. (1999), Magnus } \\
\text { et al. (2002), Sheard and Dick (2003), } \\
\text { Hrabak et al. (2004), Rocha and Teixeira } \\
\text { (2005b), Teixeira and Rocha (2006) }\end{array}$ \\
\hline
\end{tabular}

Hypothesis 1 The likelihood of copying is greater when students expect to obtain a higher mark/grade by copying.

Hypothesis 2 The probability of copying is higher the greater the difference between the mark/grade the students say they expect if they do in fact copy, and the mark/grade they will likely obtain if no copying takes place. 
Contextual factors

The role situational factors play in affecting the decision to cheat has garnered a significant amount of recent attention. Consistent with Ford and Richardson (1994, p. 212), situational/ contextual factors include the "pressures which come to bear on the individual to encourage or discourage ethical decision making". Contextual factors and the environment-peer pressure and attitudes towards academic dishonesty are considered by a greater number of studies (e.g., Houston 1986; Lanza-Kaduce and Klug 1986; Ward and Tittle 1993) as conditioning factors for the development of illicit academic practices. In fact, Bunn et al. (1992) found that the likelihood of copying is directly related to observing others doing so, and the perception of the number of students who routinely copy. In other words, the probability of a student having already copied is conditioned by his/her beliefs in relation to other students who copy. Furthermore, these authors assess the perception students have regarding the severity of the punishment applied if they are caught copying and use this and indicators of the climate of cheating perceived by students to evaluate their perception of the percentage who copy. They find evidence for the belief among students that, given the negligible effect of intimidation attached to expected punishments, they are very unlikely to be caught copying. In addition they find that students do not think copying is a serious crime, which could contribute to a greater incidence of this phenomenon.

Hypothesis 3 In copying-favourable environments where permissibility and permeability towards copying is high, students' propensity to copy tends to be higher.

Hypothesis 4 The higher and more serious the perceived sanctions are, the fewer the incentives students have to perpetrate dishonest behaviours.

\section{Honour codes}

Since the early twentieth century, researchers have taken particular interest in the effectiveness of honour codes. For instance, Campbell (1935) reported that, in instances where honour guarantees were used, students were less likely to cheat than students placed in traditional proctor conditions. This finding has been replicated as recently as 1993 . In an extensive survey of 6,090 students, McCabe and Trevino (1993) found that students under honour systems reported significantly lower levels of cheating than students without honour codes. Interestingly, the acceptance of the policy, the likelihood of being reported, and the severity of the penalty for being caught, all influenced the likelihood that students would refrain from cheating. Perhaps most interesting is their finding that the perceived behaviour of peers was the most important factor in predicting cheating behaviours. May and Loyd (1993) also found a significant drop in cheating among students at universities with honour codes. Although McCabe et al. (2003) do not analyze directly the influence of codes of honour on the probability of copying, they examine whether this variable has an effect on the academic integrity of university staff in terms of their attitudes and behaviours. The analysis is based on universities with and without codes of honour. The authors found that universities which have a code of honour have more positive attitudes towards policies of academic integrity and are more willing to allow the system to take measures to warn and discipline students. Furthermore, they confirmed that, in the absence of a code of honour, university faculty members with this experience believe in students being responsible for monitoring their colleagues, recognizing the fairness and efficiency of their institutions' policies of academic integrity. Following this line of argument we hypothesize here that: 
Hypothesis 5 In universities where 'codes of honour' exist, the propensity to copy among students is lower.

\section{Countries/social and cultural factors}

Differences in social factors are likely to comprise an important factor in explaining students' propensity to cheat. For instance, Diekhoff et al. (1999) detected differences and similarities in American and Japanese students copying in exams. Weighting the limitation associated with the distinct composition of the two samples (both in terms of size and associated with various demographic characteristics, such as gender, age and school year), the data showed that in comparison with the Americans, the Japanese students are more prone to copy in exams. With regard to social involvement, Diekhoff et al. (1999) considered that if copying is viewed as widespread, it is harder for Japanese students to resist to the pressure of copying or to help their colleagues to do so, given the group and team orientation among Japanese students. In a complementary way, Magnus et al. (2002) conducted an experiment on students in secondary, higher and postgraduate education, in five different regions-Moscow, Russia (province), the Netherlands, the USA and Israeland showed that both the level of teaching and the zone lead to students having distinct opinions relative to academic dishonesty. More recently, Teixeira and Rocha (2006) showed that differences in undergraduate copying propensities are significant, with Romania and Spanish students revealing a higher propensity towards fraudulent behaviours than their Austrian and especially their Portuguese counterparts. Thus we hypothesize that:

Hypothesis 6 The propensity to copy is influenced by the countries' cultural/educational systems and social and business ethics-related factors.

\section{Gender}

Crown and Spiller (1998) in a review of studies on cheating argued that the relationship between gender and cheating appears to have become more tenuous in the recent past. Earlier studies, such as that by Bushway and Nash (1977), concluded that engagement in cheating behaviours among female students was lower than among their male counterparts. With the exception of Karebenick and Srull (1978) and Graham et al. (1994), the studies published after 1982 did not find significant gender differences. Surprisingly, a more recent study, focusing also on gender differences, reported that females were more likely to admit to cheating than males (Graham et al. 1994). An explanation for this diminishing distinction in gender differences may be found in Ward and Beck's (1990) work. They noted that sex-role socialization is thought to influence the tendency towards dishonesty through differences in internalized role requirements. The prevailing non-significant relationship between gender and cheating over the last few years might suggest a convergence in role requirements among males and females in collegiate settings. In Rocha and Teixeira's (2005b) study, females were found to cheat significantly less than males. Additional studies (Kerkvliet 1994; Nowell and Laufer 1997; Kerkvliet and Sigmun 1999; Tibbets 1999; Hrabak et al. 2004) focused on this relation but without any clear-cut view on the matter.

Age

Several studies (e.g., Barnes 1975; Baird 1980; Michaels and Miethe 1989; Haines et al. 1986; Graham et al. 1994) reported significant age-cheating relationships, while Antion 
and Michael (1983) and Daniel et al. (1991) did not find a significant correlation. Unfortunately, the importance of age effects is difficult to detect in the literature on cheating. In most studies, age is restricted to a 5-year span in addition to being highly correlated with class. In the one study that focused on traditional versus non-traditional age students, Graham et al. (1994) found that the former cheated more than the latter. Studies assessing differences within the traditional age span have produced mixed findings. Barnes (1975) and Michaels and Miethe (1989) found that older students were more likely to cheat, whereas Baird (1980) and Haines et al. (1986) reported that younger students cheated more frequently. Similarly to this latter study, Rocha and Teixeira (2005b) found that younger undergraduates are more likely to commit academic misconduct.

\section{Year of study}

The year in school has been reliably associated with cheating attitudes and behaviour, with attitudes toward cheating becoming more negative and cheating behaviour declining with the progression in year in school (Davis et al. 1992; Diekhoff et al. 1996; Haines et al. 1986). Diekhoff et al. (1999), however, found that their more mature/senior Japanese sample actually engaged in more cheating than students in their American sample. In the same line, Nowell and Laufer (1997) found that seniors, who, according to the authors, would have little to gain in terms of overall change in G.P.A., were somewhat less likely to cheat than freshmen (first-year students).

\section{Student status}

Previous research highlights the importance of the students' workload. Nowell and Laufer (1997) found that an increased workload was positively related to the probability of cheating. Students who were employed either part-time or full-time were more likely to cheat than students who were not employed. Thus cheating propensity is likely to be dependent on student status, that is, whether they were regular/full-time students or parttime students combining employment (Working Students, WSs) or other student-related tasks (Association Members, AMs).

\section{Methodological issues and exploratory description of the data}

Cheating is a complex issue. When exploring students' cheating behaviour in university institutions there are many aspects to consider. It is not surprising, therefore, that a reading of the literature has led to a lack of any type of simple definition (Sheard et al. 2003). Typically, cheating is described in terms of a series of practices, which cover a range of areas that can be defined as illegal, unethical, immoral or against the regulations of the course or institution (see Table 1). The difficulty of clearly defining cheating is aggravated by differences across institutions and also across disciplines of study (Maramark and Maline 1993). Some practices, however, may be universally accepted as cheating, for example, paying someone to sit an examination or copying in exams (by a colleague and/or using prohibited written/taped/saved notes in papers, cell phones, calculators, etc.) (Sheard et al. 2003). Copying in exams is considered a simple measure of basic honesty (Cabral-Cardoso 2004); nevertheless, given its broad meaning in this study, and in the line of, for instance, Bunn et al. (1992) and McCabe et al. (2006), we have defined cheating behaviour as copying in exams. Furthermore, Bisping et al. (2008), who studied the determinants of academic dishonesty considering 31 distinct type of 
misconduct, including copying in exams, observed that, notwithstanding that the percentage of students who stated they had engaged in each of them differed substantially, the general trends regarding the signs and the statistical significance of the determinants (age, G.P.A., year, gender, ...) do not noticeably differ among the distinct types of misconduct. This latter evidence supports the view that restricting the definition of academic cheating to copying in exams, albeit limited, might not be so detrimental in terms of results and implications.

Measuring cheating in academia is not an easy task and researchers have generally used their own information to gather data for assessing this type of behaviour (Nowell and Laufer 1997). The literature points to four main ways to obtain data on academic fraud (Kerkvliet and Sigmun 1999): direct yet discrete observation of the data; the "overlapping error" method; the random answer questions method, and inquiry via the direct questions method. In this study, we have opted for the latter method. Although this method takes no account of problems associated with sensitivity to the kind of questions asked (like the random answers method), meaning that it can induce deviation in the estimates of academic dishonesty (Kerkvliet and Sigmun 1999), it does have simplicity of implementation in its favour, and a wealth of output for analysis. This is why it is often the procedure used (Bunn et al. 1992; Magnus et al. 2002; Sheard and Dick 2003; Hrabak et al. 2004). ${ }^{5}$

We devised a one-page questionnaire (see Appendix) in line with Bunn et al. (1992) covering a range of questions focusing on the main determinants associated with academic fraudulent behaviour, adding new variables/questions which in our view are likely to influence the propensity to copy (section "On the magnitude and determinants of academic cheating"). The target group was 2nd, 3rd and 4th year students from Economics and Business/Management courses. The questionnaire was implemented in 11 Portuguese Universities (all public universities from the mainland and the University of the Azores), and 31 schools/universities in 20 other countries. In operational terms, for the majority of schools, the questionnaires were implemented in the classroom (in general, classes with the highest number of enrolled students were targeted).

For schools in countries such as Brazil, Colombia, France, and Poland, students filled an on-line questionnaire similar to the one the other students filled in class. The on-line option was chosen following the suggestions of professors/researchers from the targeted schools given the difficulty, within a reasonable time span, to assemble a sufficient number of students in class. The survey was conducted between March 2005 and May 2006, resulting in 7,213 valid responses.

Reflecting the number of schools surveyed, the number of responses from Portuguese students totalled almost $40 \%$ of the overall responses. The others were distributed, by decreasing order of responses, as follows: Spain with $22 \%$ of the remaining total; Turkey and Austria with about $12 \%$; Slovenia, New Zealand and Germany with approximately $7 \%$; Italy, Nigeria and UK with between 5 and 6\%; with around 2\% we have Mozambique, Brazil, Romania, Ireland, Denmark, and Argentina; finally, the least representative countries with about $1 \%$ of the remaining total, France, Colombia, Sweden, USA, and Poland (Table 3).

Given the low representativeness of the responses for some countries and the pertinence of the analysis, we thought it advisable to additionally aggregate countries into eight meaningful blocks, as represented in Fig. 1.

Our worldwide survey on copying propensity among economics and business undergraduate students points to an average cheating propensity of $61.7 \%$. Thus, similarly to the studies surveyed in section "On the magnitude and determinants of academic cheating",

\footnotetext{
5 Rocha and Teixeira (2005a) provide a detailed description of the different methods.
} 
Table 3 Countries, schools and number of students that participated in the survey

\begin{tabular}{lcccc}
\hline Country & $\begin{array}{l}\text { Number of schools/ } \\
\text { universities }\end{array}$ & $\begin{array}{l}\text { Number of } \\
\text { responses }\end{array}$ & $\begin{array}{l}\text { \% Total } \\
\text { responses }\end{array}$ & $\begin{array}{c}\text { \% Total responses } \\
\text { (excl. Portugal) }\end{array}$ \\
\hline Argentina & 1 & 75 & 1.0 & 1.7 \\
Austria & 1 & 519 & 7.2 & 11.8 \\
Brazil & 1 & 100 & 1.4 & 2.3 \\
Colombia & 1 & 44 & 0.6 & 1.0 \\
Denmark & 1 & 78 & 1.1 & 1.8 \\
France & 2 & 62 & 0.9 & 1.4 \\
Germany & 3 & 305 & 4.2 & 6.9 \\
Ireland & 1 & 79 & 1.1 & 1.8 \\
Italy & 2 & 279 & 3.9 & 6.3 \\
Mozambique & 1 & 115 & 1.6 & 2.6 \\
New Zealand & 1 & 315 & 4.4 & 7.1 \\
Nigeria & 1 & 237 & 3.3 & 5.4 \\
Poland & 1 & 20 & 0.3 & 0.5 \\
Portugal & 11 & 2,805 & 38.9 & \\
Romania & 2 & 99 & 1.4 & 2.2 \\
Slovenia & 2 & 321 & 4.5 & 7.3 \\
Spain & 3 & 955 & 13.2 & 21.7 \\
Sweden & 1 & 44 & 0.6 & 1.0 \\
Turkey & 2 & 528 & 7.3 & 12.0 \\
UK & 2 & 197 & 2.7 & 4.5 \\
US & 2 & 36 & 0.5 & 0.8 \\
Total & 42 & 7,213 & 100.0 & 100.0 \\
\hline & & & & \\
& & & & \\
\end{tabular}

we conclude that the phenomenon of cheating in Universities has reached a relatively high magnitude. Recall that studies using a comparable definition of academic cheating and data gathering methodology to the one presented here estimated copying probabilities of between 50\% (Bunn et al. 1992) and 62\% (Rocha and Teixeira 2005b). Focusing also on copying practices Hrabak et al. (2004) indicated figures between 34.6 and 52.2\%.

The interesting contribution of our study derives from the striking differences in cheating behaviours between (blocks of) countries. In fact, from Fig. 2, the striking differences are apparent, for instance, between the Scandinavian countries, whose average propensity to cheat is below 5\%, and the Eastern European countries with an average cheating propensity of $87.9 \%$. The Latin American and Southern European blocks present rather similar averages, 67.9 and $66.4 \%$, respectively. In the US and British Isles (Ireland and the UK) block, around $17 \%$ of the students surveyed admitted to having cheated, which is not far from the percentage of their New Zealand (Oceania) counterparts $(20.7 \%)$. Quite surprising are the figures pertaining to copying propensity in the African block (Mozambique and Nigeria), where around 'only' half of the students admitted to fraudulent conduct.

Distinguishing between the frequency with which students in each country and block of countries commit illicit behaviours during exams provides interesting patterns. Countries from Eastern Europe, in particular Poland and Romania, and Latin America, namely Brazil, present the highest percentages of students who admitted to copying in exams often or always. In shear contrast, we have Oceania (New Zealand), the US and the British Isles, 


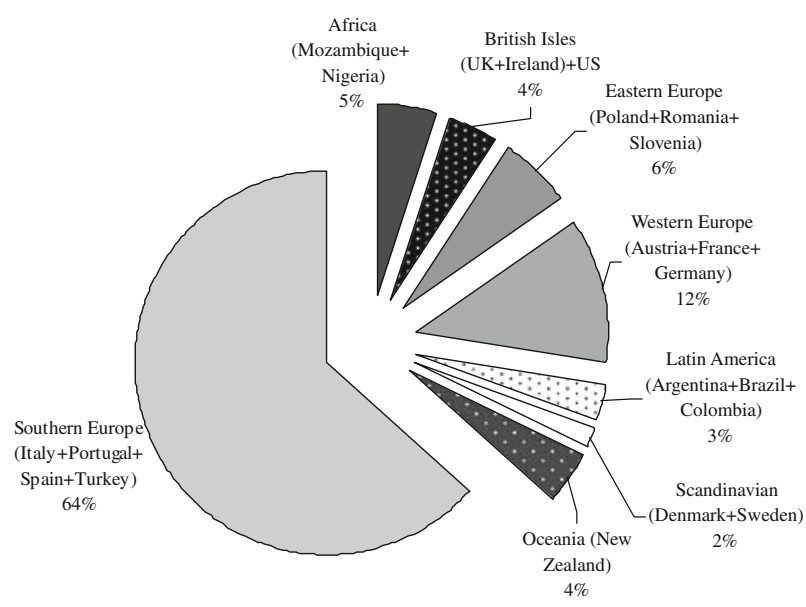

Fig. 1 Distribution of the responses by blocks of countries. Source: calculations made by the authors based on direct survey conducted in the periods February 2005-May 2006

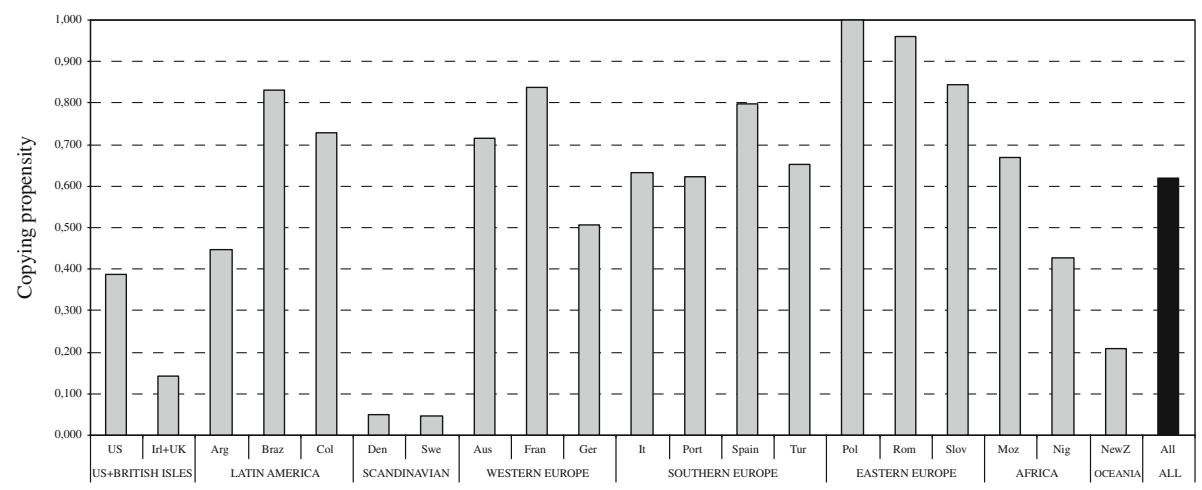

Fig. 2 Probability of 'copying' by (blocks of) countries. Source: calculations made by the authors based on direct survey conducted in the periods February 2005-May 2006

and the Scandinavian countries where a meagre percentage of students (below $0.8 \%$ ) admitted to this practice. Specifically Sweden, where no student admitted copying with high frequency, and Ireland and the UK, emerge as the least prone to having a very regular propensity towards cheating. The Western and Southern European blocks present very similar figures (3.1 and 3.7\%, respectively), contrasting (from a negative perspective) with Austria (4.2\%) and Turkey (6.6\%) within these blocks. Notable are the figures from the African block, in particular Mozambique, with only $1 \%$ of the total respondent students admitting to copying with regularity.

Analyzing the percentages of students that claimed to have never copied, once again the Scandinavian, the US and British Isles, and the New Zealand blocks, emerge here as having the 'more honest' undergraduates. In these (blocks of) countries, $80 \%$ and over of the respondents stated they had never committed fraud in exams. By contrast, the Eastern European countries (especially Poland), France, Brazil and Turkey, come up with the lowest percentages in this regard, ranging from $0 \%$ (Poland) to $20 \%$ (Turkey) of the total students claiming never to have copied. 
Observing other students copying (Tables 4, 5) may constitute an indirect measure of cheating propensity and a reasonable indicator of the generalization of the cheating 'culture'. It is alarming that for all the countries analyzed almost $90 \%$ of the students admitted to having seen others cheating during exams-approximately one-third claimed to have observed this type of behaviour often or always!

The cheating 'culture' seems pervasive in Latin America, where generally all the students had observed others copying (45\% admitted to have seen the phenomenon regularly), Eastern Europe (particularly Poland and Romania), and Southern Europe (namely Turkey). Quite differently, the phenomenon is seldom observed in the Scandinavian countriesaround $80 \%$ of the respondents had never observed other colleagues cheating in examinations. In New Zealand and the British Isles, approximately half of the students stated never having seen others copying. Regarding the observation of copying with some

Table 4 Frequency of copying by countries and country blocks

\begin{tabular}{|c|c|c|c|c|c|}
\hline \multirow[t]{2}{*}{ Countries/blocks } & \multicolumn{3}{|c|}{$\%$ of total students in each country/block } & \multirow{2}{*}{$\begin{array}{l}\text { Probability } \\
\text { of copying }(\%)\end{array}$} & \multirow{2}{*}{$\begin{array}{l}\% \text { Total responses } \\
(n=7,139)\end{array}$} \\
\hline & Never & Sometimes & Often & & \\
\hline British Isles (Irl + UK) & 85.6 & 14.0 & 0.4 & 14.4 & 4.3 \\
\hline United States & 61.1 & 36.1 & 2.8 & 38.9 & \\
\hline US_BI & 82.7 & 16.6 & 0.7 & 17.3 & \\
\hline Argentina & 55.4 & 43.2 & 1.4 & 44.6 & 3.1 \\
\hline Brazil & 17.0 & 72.0 & 11.0 & 83.0 & \\
\hline Colombia & 27.3 & 70.5 & 2.3 & 72.7 & \\
\hline Latin America & 32.1 & 61.9 & 6.0 & 67.9 & \\
\hline Denmark & 94.9 & 3.8 & 1.3 & 5.1 & 1.7 \\
\hline Sweden & 95.5 & 4.5 & 0.0 & 4.5 & \\
\hline Scandinavian Countries & 95.1 & 4.1 & 0.8 & 4.9 & \\
\hline Austria & 28.4 & 67.5 & 4.2 & 71.6 & 12.1 \\
\hline France & 16.1 & 80.6 & 3.2 & 83.9 & \\
\hline Germany & 49.3 & 49.3 & 1.3 & 50.7 & \\
\hline Western Europe & 34.7 & 62.2 & 3.1 & 65.3 & \\
\hline Italy & 36.6 & 60.1 & 3.3 & 63.4 & 63.6 \\
\hline Spain & 37.6 & 60.0 & 2.4 & 62.4 & \\
\hline Turkey & 20.4 & 73.0 & 6.6 & 79.6 & \\
\hline Portugal & 34.6 & 60.4 & 5.0 & 65.4 & \\
\hline Southern Europe & 33.6 & 62.7 & 3.7 & 66.4 & \\
\hline Poland & 0.0 & 85.0 & 15.0 & 100.0 & 6.1 \\
\hline Romania & 4.0 & 81.8 & 14.1 & 96.0 & \\
\hline Slovenia & 15.4 & 78.3 & 6.3 & 84.6 & \\
\hline Eastern Europe & 12.1 & 79.4 & 8.5 & 87.9 & \\
\hline Mozambique & 33.7 & 65.3 & 1.0 & 66.3 & 4.8 \\
\hline Nigeria & 57.4 & 39.1 & 3.5 & 42.6 & \\
\hline Africa & 49.3 & 48.1 & 2.6 & 50.7 & \\
\hline New Zealand & 79.3 & 20.1 & 0.6 & 20.7 & 4.3 \\
\hline All Countries & 38.3 & 58.1 & 3.6 & 61.7 & 100 \\
\hline
\end{tabular}

Calculations made by the authors based on direct survey conducted in the periods February 2005-May 2006 
Table 5 Frequency of 'observing others copying' by countries and blocks of countries

\begin{tabular}{|c|c|c|c|c|c|}
\hline \multirow[t]{2}{*}{ Countries/blocks } & \multicolumn{3}{|c|}{$\%$ of total students in each country/block } & \multirow{2}{*}{$\begin{array}{l}\text { Probability of } \\
\text { observing } \\
\text { copying (\%) }\end{array}$} & \multirow{2}{*}{$\begin{array}{l}\text { \% Total responses } \\
(n=7,171)\end{array}$} \\
\hline & Never & Sometimes & Often & & \\
\hline British Isles (Irl + UK) & 47.5 & 46.7 & 5.8 & 52.5 & 4.4 \\
\hline United States & 13.9 & 75.0 & 11.1 & 86.1 & \\
\hline US_BI & 43.6 & 50.0 & 6.4 & 56.4 & \\
\hline Argentina & 4.0 & 70.7 & 25.3 & 96.0 & 3.1 \\
\hline Brazil & 0.0 & 35.0 & 65.0 & 100.0 & \\
\hline Colombia & 0.0 & 65.9 & 34.1 & 100.0 & \\
\hline Latin America & 1.4 & 53.3 & 45.3 & 98.6 & \\
\hline Denmark & 79.5 & 17.9 & 2.6 & 20.5 & 1.7 \\
\hline Sweden & 81.8 & 18.2 & 0.0 & 18.2 & \\
\hline Scandinavian Countries & 80.3 & 18.1 & 1.6 & 19.7 & \\
\hline Austria & 11.0 & 68.6 & 20.4 & 89.0 & 12.2 \\
\hline France & 4.8 & 51.6 & 43.5 & 95.2 & \\
\hline Germany & 18.5 & 71.3 & 10.2 & 81.5 & \\
\hline Western Europe & 13.1 & 68.3 & 18.6 & 86.9 & \\
\hline Italy & 12.0 & 52.6 & 35.4 & 88.0 & 63.4 \\
\hline Spain & 7.5 & 68.6 & 23.9 & 92.5 & \\
\hline Turkey & 2.6 & 47.3 & 50.1 & 97.4 & \\
\hline Portugal & 7.6 & 54.4 & 38.0 & 92.4 & \\
\hline Southern Europe & 6.8 & 61.5 & 31.7 & 93.2 & \\
\hline Poland & 0.0 & 70.0 & 30.0 & 100.0 & 6.1 \\
\hline Romania & 1.0 & 38.4 & 60.6 & 99.0 & \\
\hline Slovenia & 6.3 & 63.7 & 30.0 & 93.7 & \\
\hline Eastern Europe & 4.8 & 58.2 & 37.0 & 95.2 & \\
\hline Mozambique & 7.0 & 61.0 & 32.0 & 93.0 & 4.8 \\
\hline Nigeria & 16.2 & 54.9 & 28.9 & 83.8 & \\
\hline Africa & 13.5 & 56.7 & 29.8 & 86.5 & \\
\hline New Zealand & 52.3 & 45.1 & 2.6 & 47.7 & 4.3 \\
\hline All Countries & 12.4 & 59.7 & 27.9 & 87.6 & 100 \\
\hline
\end{tabular}

Calculations made by the authors based on direct survey conducted in the periods February 2005-May 2006

regularity, the percentages are quite high ( $\sim 70 \%$ or more) in countries such as the United States, Argentina, Poland, Austria and Spain.

The pervasiveness of cheating is further confirmed by the percentage of students who acknowledged knowing someone of their closer relations who copied regularly-in Spain, Brazil, Romania, Slovenia and Colombia, the percentage is around $80 \%$ or higher.

Such pervasiveness is to a large extent explained by the opinion and attitude of students regarding these illicit behaviours. From our results we found that, overall, only $12.2 \%$ of the respondent students reckoned that cheating is a serious problem and around one-third recognized that it warrants some concern. For the majority $(60 \%)$, cheating is not a problem or is at most a trivial one.

As expected, in the Scandinavian countries, this phenomenon is considered a 'nonissue' - more than $80 \%$ of the students did not consider copying in examinations a problem or 
it was only a minor one. Interesting are the results gathered from Nigeria, Mozambique and Argentina. In these countries, copying in exams is considered, by a considerable proportion of the undergraduates (over 70\%), a serious problem or a problem that deserves some attention. Albeit the considerable amount of fraudulent behaviour among undergraduates in these countries, they seem to be aware of the relevance of the matter. The Eastern European countries, despite having even more troubling rates of copying than the countries mentioned above, do not seem to acknowledge cheating as an important issue which warrants some concern and require appropriate measures. For instance, in Slovenia and Poland, where the magnitude of cheating is paramount, a large majority of the students do not perceive cheating as a problem. This is also the case of Austria, Spain and Brazil (Fig. 3).

Troublesome is the fact that, not only did the students reckon that copying is a minor problem, but a large percentage (around $40 \%$ of total respondents) argued that copying is an intentional act. Only $17 \%$ admitted that copying occurred due to panic.

The countries where a higher percentage of students identified copying with panic situations are in general those where fraud in academia is less expressive-Sweden, Denmark, the British Isles and New Zealand.

Significantly, and an issue which requires reflection, countries which are more prone to illegal behaviour-Romania, Slovenia, Brazil, Spain, France — tend to regard copying as an intentional act to a larger extent. Likewise, in Portugal and the US a significant proportion of the students recognize that copying is intentional (Fig. 4).

Another disturbing finding is that more than half of the students asserted that they would study less if there were no supervision/vigilance and/or sanctions for illegal practices in exams. In Poland, a country where, according to our data, cheating is widespread, the figure reaches three-quarters of the students. In other Eastern European countries, such as Slovenia and Romania, the percentages are also disturbing (68.9 and 56.1\%, respectively). In three Southern European countries, Turkey (66\%), Spain (65.8\%), and Italy (57.5\%), as well as France $(56.5 \%)$, the figures are also quite alarming. In these countries, as can be seen in Fig. 5, academic environments are quite permissive to illicit behaviour-the highest penalty students expect from deceitful acts is that their exam be annulled. In countries where the incidence of academic fraud is lower-the Scandinavian block and New Zealand-students expect more serious consequences for misconduct, such as a year's suspension from university. In Nigeria, a large percentage of the students $(41 \%)$ anticipate severe sanctions for fraudulent acts.

In Spain, a very high percentage $(64 \%)$ of students that admitted to having copied at some time, were caught by professors and/or supervisors/vigilantes. That figure is also high for Argentina. However, in general, the percentage of students that admit to cheating and were also caught doing so is relatively low (less than $20 \%$ for the overall sample).

Nevertheless, a reasonable percentage (around 60\%) of the (total) students has, at some time, seen other colleagues being caught committing fraud. That percentage is astonishingly high for Eastern European countries, Brazil, Colombia, Nigeria and Italy.

This, however, did not prevent the rise in illicit practices in these countries, which further sustains the inconsequentiality of the sanctions expected by students when caught in fraudulent behaviours.

A particularly efficient system is that of Denmark, where one quarter of the (smallest number of) students who admitted to copying is caught. In Sweden although no student admitted to having ever been caught, and none of them had seen anyone else get caught either (Figs. 6, 7).

In terms of the characteristics of the students surveyed, the data gathered point to a slightly higher probability of copying among female students (62.4 vs. 61.4\%). However, 


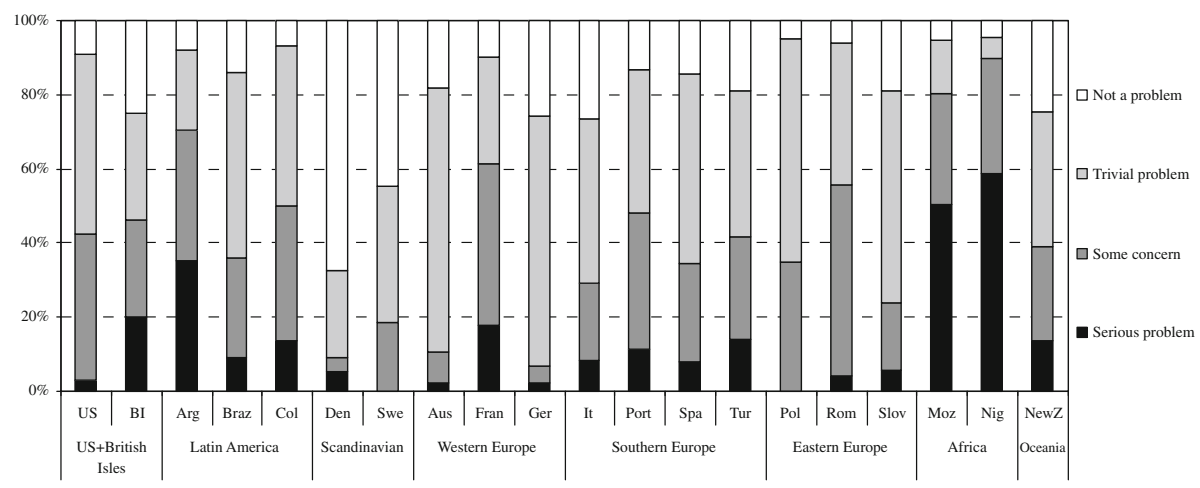

Fig. 3 Students' opinions regarding copying by block/country. Source: calculations made by the authors based on direct survey conducted in the periods February 2005-May 2006

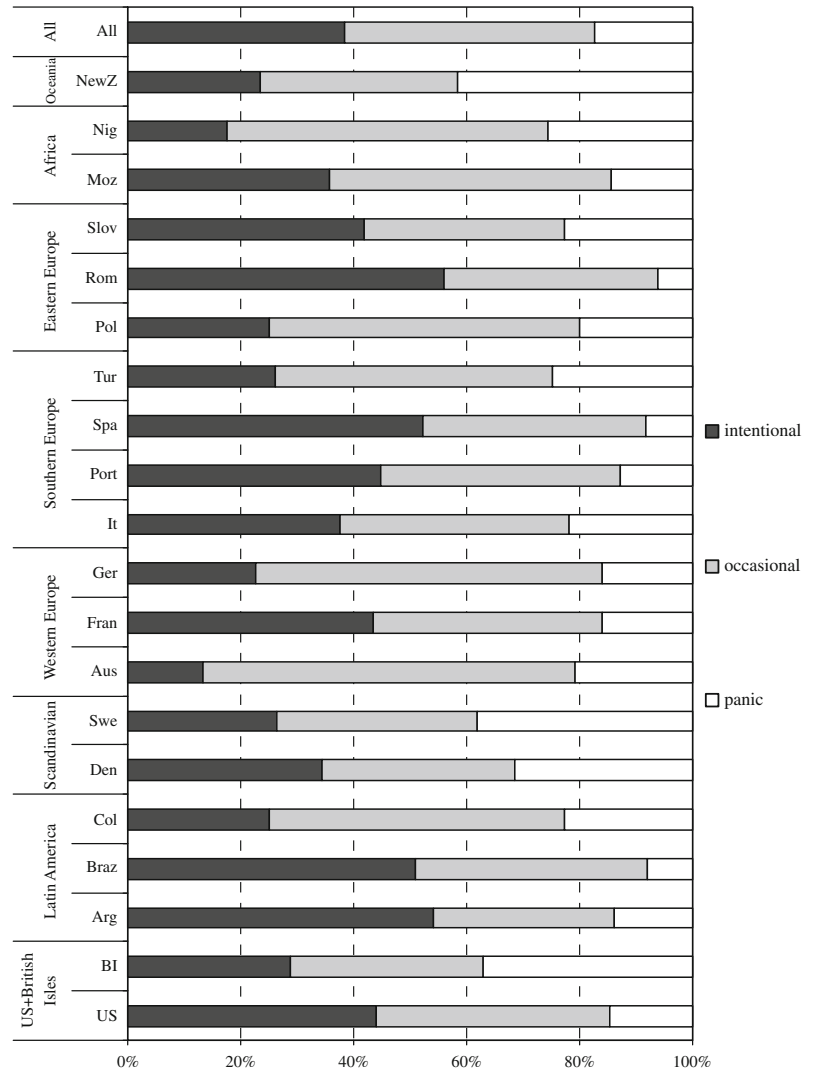

Fig. 4 Type of copying by block/country. Source: calculations made by the authors based on direct survey conducted in the periods February 2005-May 2006 


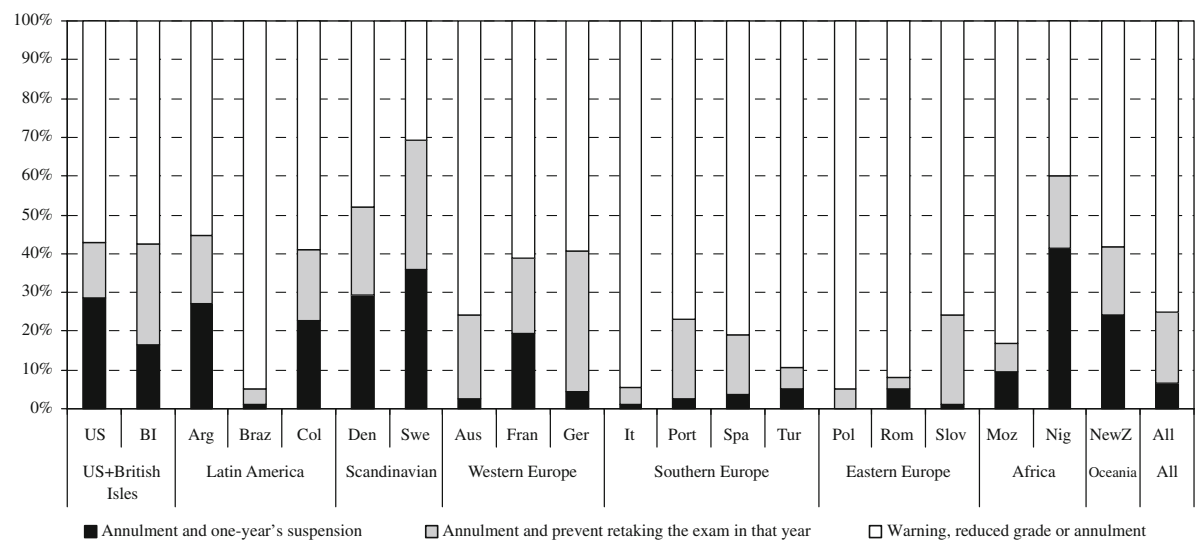

Fig. 5 Expected sanction for copying by block/country. Source: calculations made by the authors based on direct survey conducted in the periods February 2005-May 2006

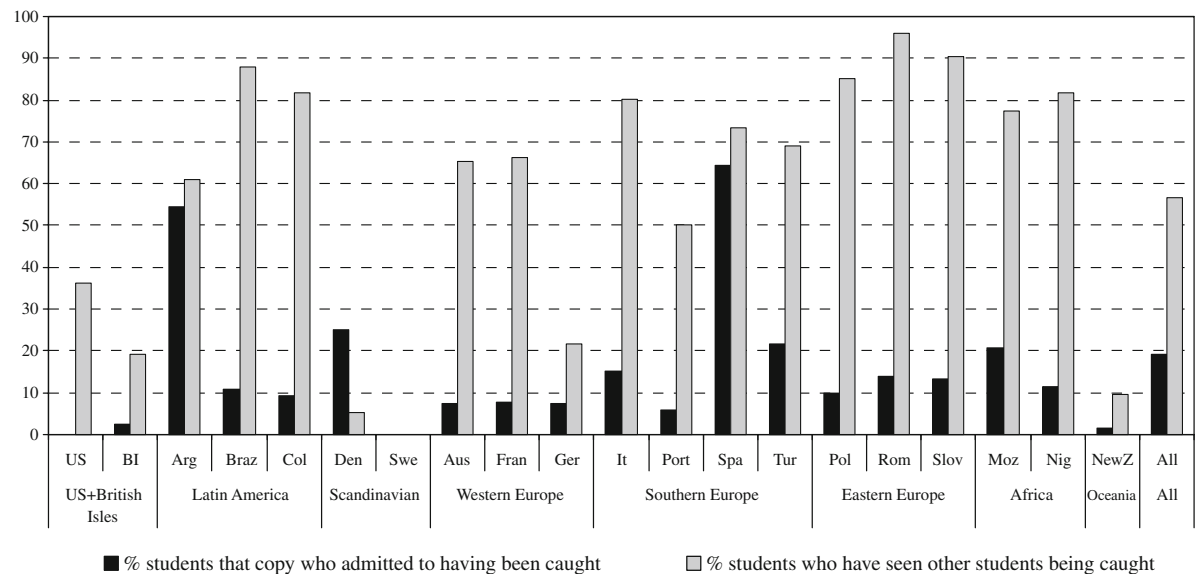

Fig. 6 Efficiency of the vigilance system by block/country. Source: calculations made by the authors based on direct survey conducted in the periods February 2005-May 2006

the picture is quite blurred when we analyze by (blocks of) countries. In Latin America, the Scandinavian countries, Eastern Europe and Africa, females do cheat more than their males counterparts. By contrast, in the US and British Isles, Western Europe, Southern Europe and New Zealand, male students reveal a higher propensity to cheat.

As can be seen in the next figure, students with intermediary ages, i.e., aged 20-25 (representing about $78.4 \%$ of the total students surveyed) registered a probability to cheat ranging between 61.7 and $67.2 \%$, much higher than the $55.6 \%$ registered among younger students (17-19 years) and 55.9\% among older students (26 and over).

Again, there is some diversity among (blocks of) countries, with Latin America, Scandinavia, Southern Europe, Africa and New Zealand following a similar path to that of the overall sample - a higher probability to copy by intermediate-aged students. In the US and British Isles and in Eastern European countries, older students are more likely to reveal illegal conduct than their younger colleagues. Differently, in Western Europe, younger 


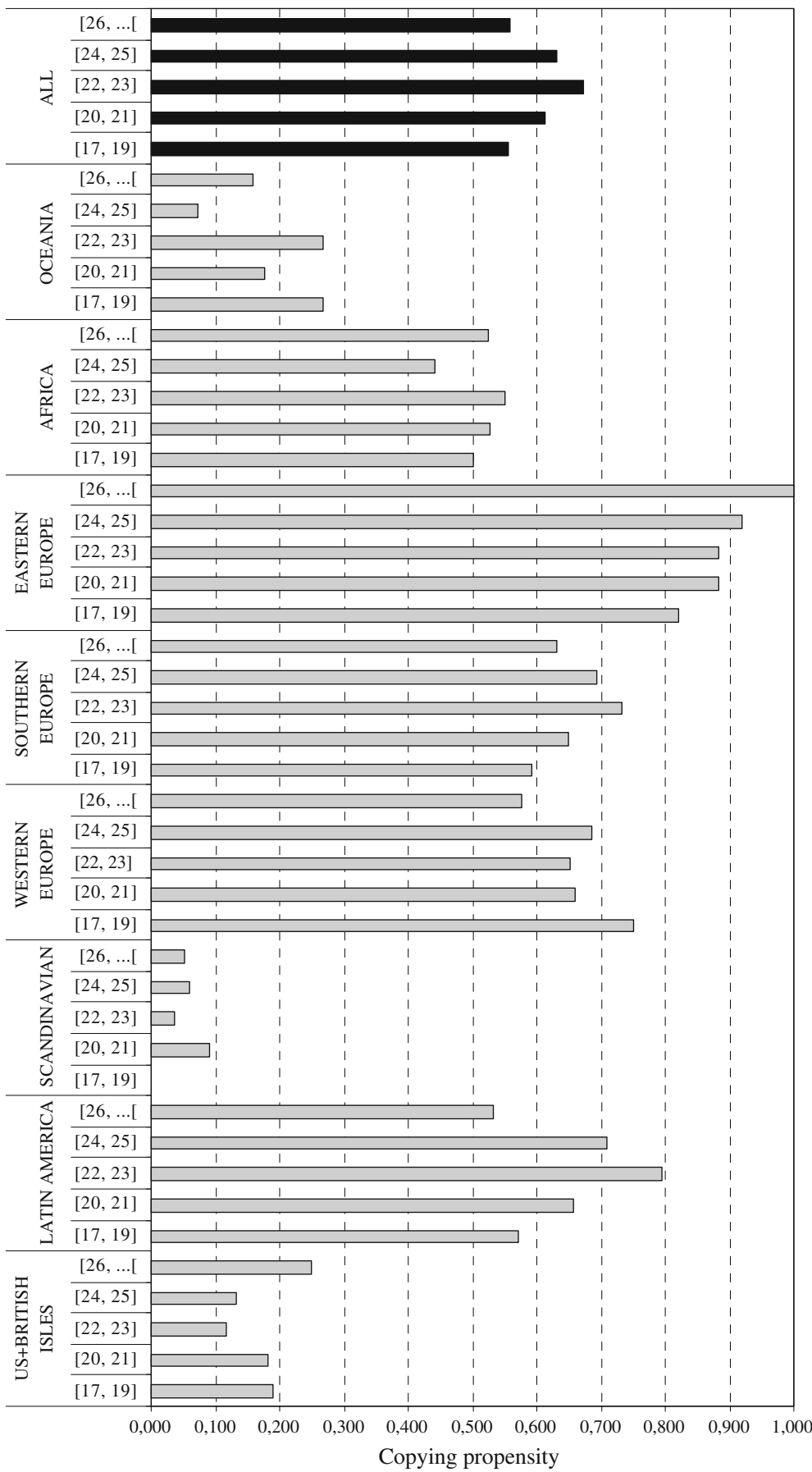

Fig. 7 Copying propensity by age and (blocks of) countries. Source: calculations made by the authors based on direct survey conducted in the periods February 2005-May 2006 
students (those aged 17-18 years old) have substantially higher copying propensities than their older colleagues (75.0 against 57.6\%).

Although at a first glance age tends to be related to the school year in which the student is enrolled, the results show a strong relationship between the propensity to copy and coming closer to concluding the degree. Students enrolled in the final year (4th year) reveal a $70.8 \%$ probability to copy whereas their colleagues in the 2nd year registered $57.8 \%$. Such results are also robust for (blocks of) countries, as is evident in Fig. 8.

Most of the students surveyed (86.3\%) are 'Regular/Normal Students'. Association Members (AMs) and Working Students (WSs) count for, respectively, 3.4 and $8.8 \%$ of all the students surveyed. ${ }^{6}$ The latter two groups revealed a greater propensity to practice dishonest acts academically, namely $62.7 \%$ (AMs) and 66.6\% (WSs), against the $61.5 \%$ of the so-called 'regular' students, which may possibly reveal that AMs and WSs have less time to dedicate to their studies.

The data in this exploratory analysis seem to confirm, albeit not as strongly as in the case of the study focusing only on Portugal (Rocha and Teixeira 2005b), an inverse relationship between students' performance (proxied by the average academic grade or G.P.A. and the respective propensity to cheat. In fact, as can be seen in Fig. 9, the students with a better academic performance (average grade of $80 \%$ or higher on a scale from 0 to 100) admit on average to a propensity to copy of $57.8 \%$, a number which is below that of their less accomplished colleagues (average grades between 50 and 60\%), who reveal a propensity to cheat of $63.6 \%$.

In cross-country terms, the inverse relationship between students' performance and the corresponding (average) propensity to cheat is also confirmed in the case of Latin America, Western Europe, Southern Europe and New Zealand (Oceania). In Eastern European and African countries, those students with intermediate average grades tend to copy more than their lower and higher performance colleagues. Oddly, it is the US and British Isles and the Scandinavian countries where top-grade students (G.P.A.s between 80 and 100\%) admit to undertaking fraudulent acts in a higher proportion than low grade students (G.P.A.s between 50 and 60\%) - respectively, 26.8 vs. $15.2 \%$ in the case of the US and British Isles, and 8.6 vs. $4.2 \%$ in case of the Scandinavian countries.

From the calculation of Pearson's linear correlation coefficient (Table 6), we find that the probability of copying appears statistically and positively correlated with the variation in the benefits gained from successful copying, the frequency of seeing other students copying and being caught copying, with the familiarity of those who copy regularly, with the influence of supervisors on time spent studying, and with the school year in which students are enrolled.

Thus, the perception of a higher grade resulting from copying encourages students to practice this act. Cheating is thus all the more probable the greater the expected difference in grades. On the other hand, seeing other students copying regularly seems to be associated with a higher probability for this practice to occur (which may reflect inefficiency in the penalties applied). Furthermore, the lower the percentage of time spent studying due to the knowledge that there will be no exam supervisors, the higher the probability of copying. Finally, students who are closer to concluding their degrees are more inclined to cheat.

Moreover, students enrolled in schools that have codes of honour are, in general, less likely to copy in examinations. In a bivariate correlation, that is, without controlling for all

\footnotetext{
${ }^{6}$ There is another category, 'Others', which includes, loosely speaking. Students from the Portuguesespeaking Countries, Erasmus students, Armed Forces, etc., who represent $1.4 \%$ of the students surveyed.
} 


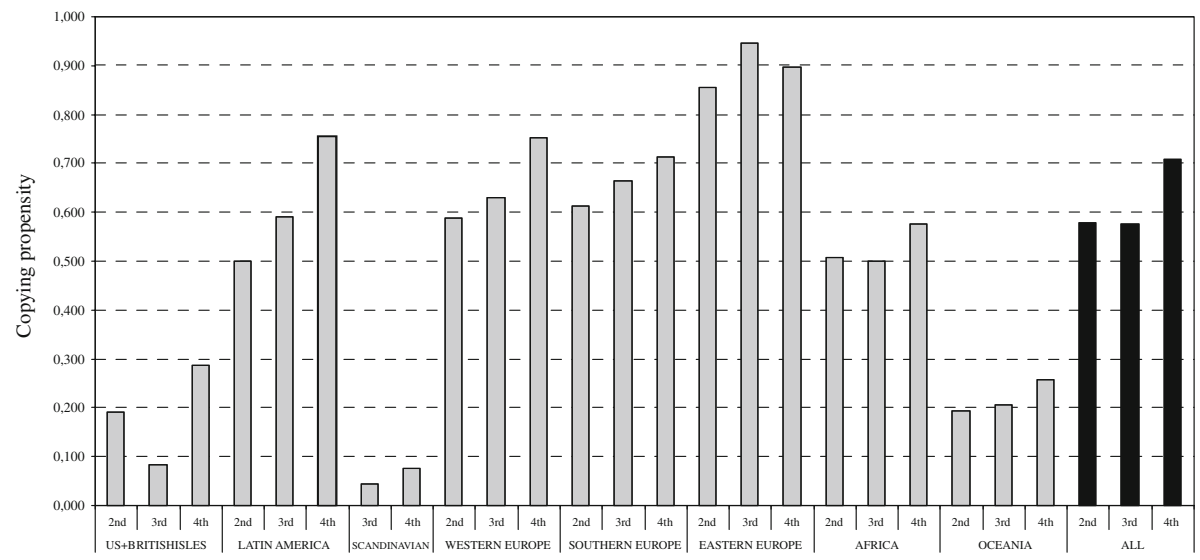

Fig. 8 Copying propensity by school year and (blocks of) countries. Source: calculations made by the authors based on direct survey conducted in the periods February 2005-May 2006

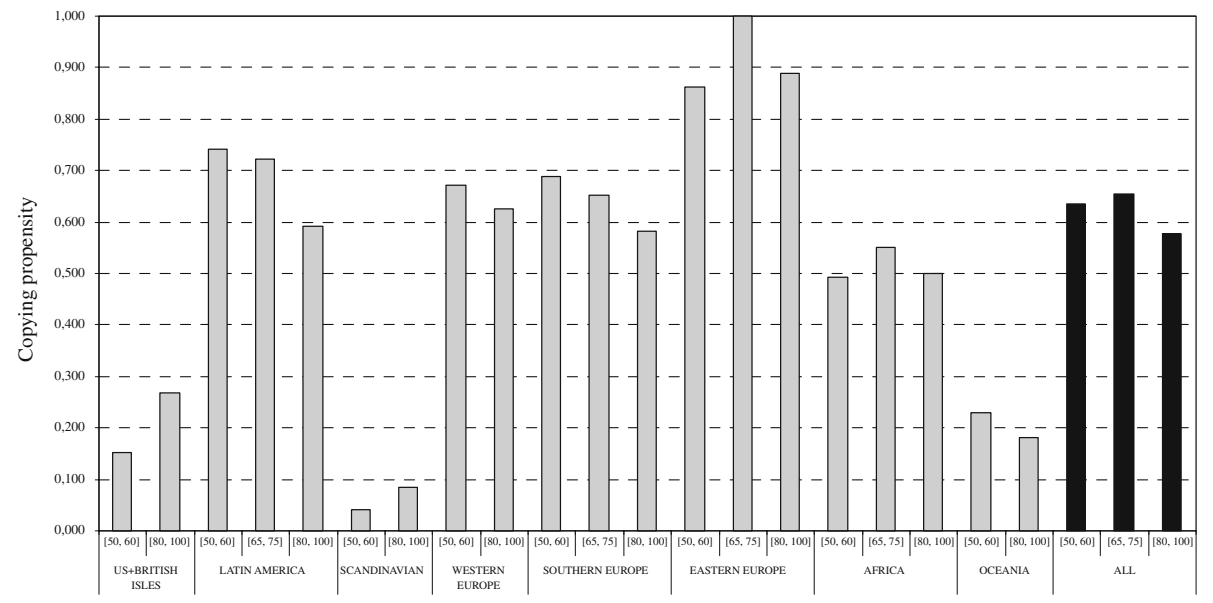

Fig. 9 Copying propensity by grade point average and (blocks of) countries. Source: calculations made by the authors based on direct survey conducted in the periods February 2005-May 2006

the potential factors affecting copying propensity, females (who amount to $55 \%$ of respondent students) are more inclined to perpetrate fraud in academia.

The G.P.A. per se, which has a sample mean of approximately $64 \%$, does not surface as significantly correlated to the probability of copying. The same happens with the students' opinion regarding copying and the students' age.

\section{Evaluating the cross-country determinants of cheating propensity}

The aim here is to assess which are the main determinants of the propensity to cheat by university students at an international level. The nature of the data collected regarding the 


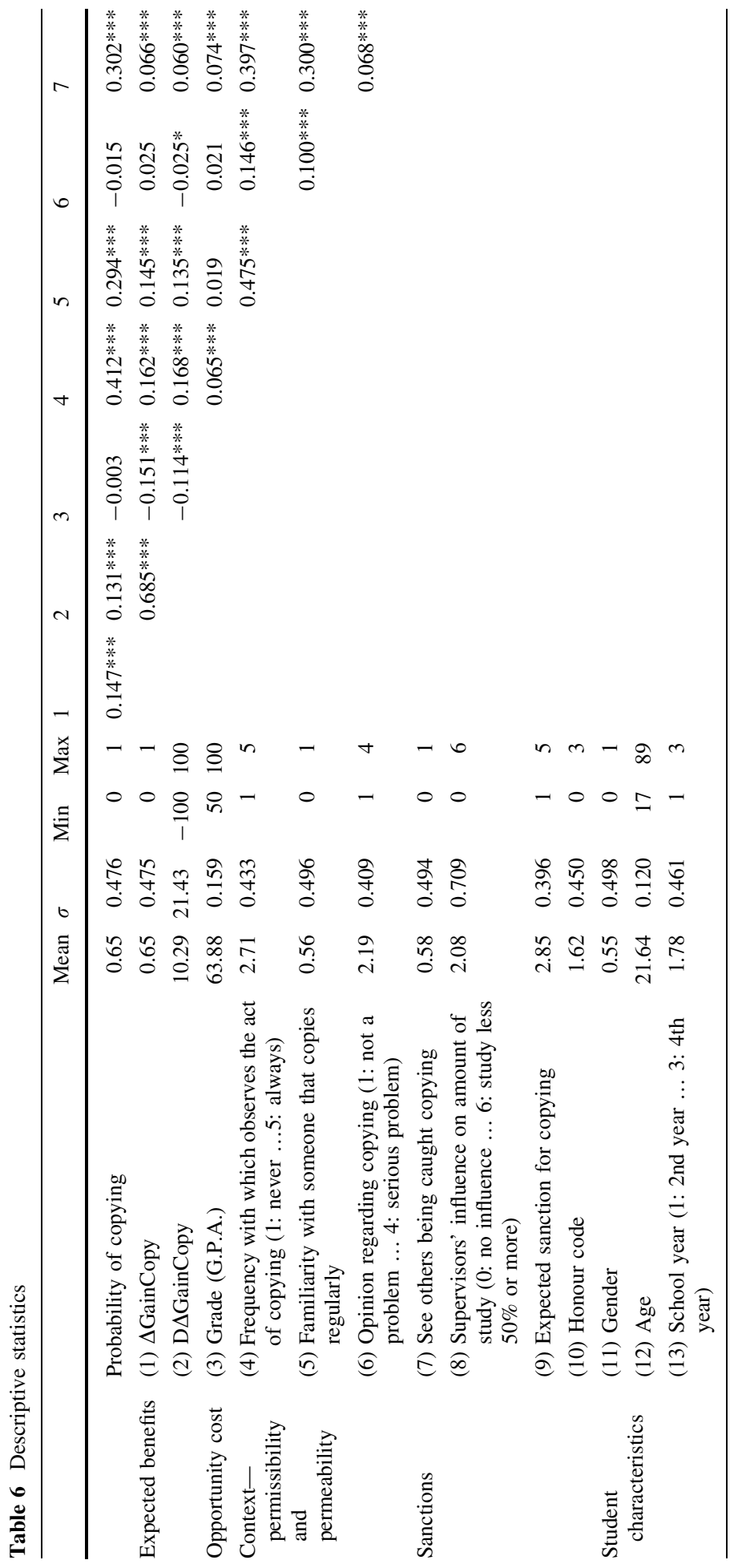




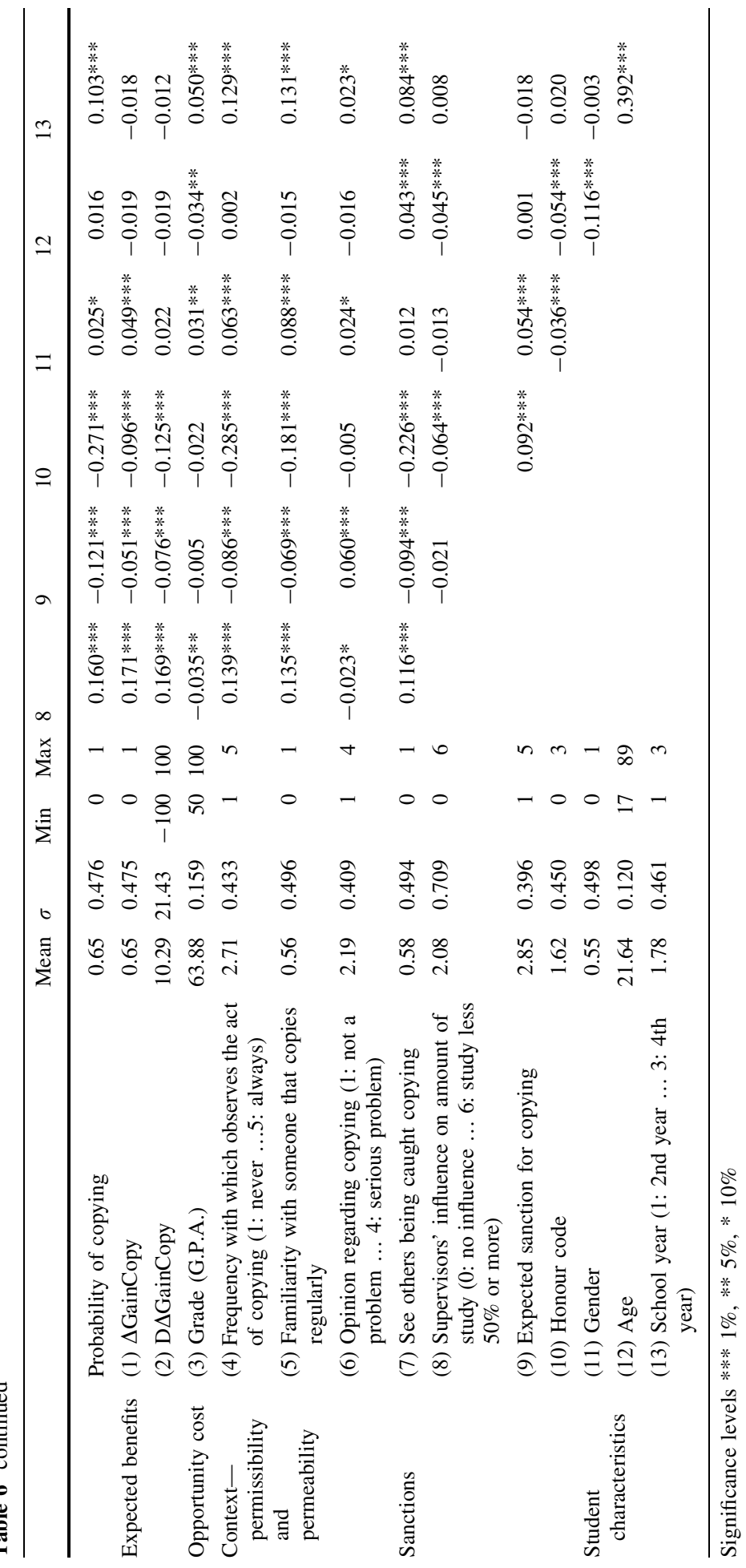


dependent variable [Have you ever copied in an exam? (1) Yes; (0) No] dictates the choice of the estimation model. Conventional estimation techniques (e.g., multiple regression analysis), in the context of a discrete dependent variable, are not a valid option. Firstly, the assumptions needed for hypothesis testing in conventional regression analysis are necessarily violated - it is unreasonable to assume, for instance, that the distribution of errors is normal. Secondly, in multiple regression analysis predicted values cannot be interpreted as probabilities-they are not constrained to fall in the interval between 0 and $1 .^{7}$ The approach used, therefore, will be to analyze each situation in the general framework of probabilistic models.

In the model of cheating likelihood, it is believed (section "Methodological issues and exploratory description of the data") that a set of factors, such as students' expected benefits/costs of copying, contextual factors, country of origin, among other variables, gathered in a vector $X$, explain the outcome, so that:

$$
\operatorname{Prob}(Y=1)=F(X, \beta) \text { and } \operatorname{Prob}(Y=0)=1-F(X, \beta) .
$$

The set of parameters $\beta$ reflects the impact of changes in $X$ on the likelihood of copying.The empirical assessment of the propensity to copy is based on the estimation of the following general logistic regression:

$$
\begin{aligned}
P(\text { copy })=\frac{1}{1+\mathrm{e}^{-Z}} ; \quad \text { with } Z= & \beta_{0}+\beta_{1} \Delta \text { GainCopy }+\beta_{2} D \Delta \text { GainCopy }+\beta_{3} \text { Grade } \\
& +\boldsymbol{\beta}_{4} \text { Contextual }+\boldsymbol{\beta}_{\mathbf{5}} \text { Sanctions } \\
& +\beta_{6} \text { HCode }+\boldsymbol{\beta}_{7} \text { StudentCharact }+\boldsymbol{\beta}_{\mathbf{8}} \text { Countries }+\varepsilon_{i}
\end{aligned}
$$

In order to have a more straightforward interpretation of the logistic coefficients, the logistic model can be rewritten in terms of the odds of an event occurring-the logit model becomes:

$$
\begin{aligned}
\log \left(\frac{\operatorname{Prob}(\text { copy })}{\operatorname{Prob}(\text { not copy })}\right)= & \beta_{0}+\beta_{1} \Delta \text { GainCopy }+\beta_{2} D \Delta \text { GainCopy }+\beta_{3} \text { Grade } \\
& +\boldsymbol{\beta}_{4} \text { Contextual }+\boldsymbol{\beta}_{\mathbf{5}} \text { Sanctions } \\
& +\beta_{6} \text { HCode }+\boldsymbol{\beta}_{7} \text { StudentCharact }+\boldsymbol{\beta}_{\mathbf{8}} \text { Countries }+\varepsilon_{i}
\end{aligned}
$$

The logistic coefficient can be interpreted as the change in the log odds associated with a one-unit change in the independent variable. Then $e$ raised to the power $\beta_{i}$ is the factor by which the odds change when the $i$ th independent variable increases by one unit. If $\beta_{i}$ is positive, this factor will be greater than one, which means that the odds are increased; if $\beta_{i}$ is negative, the factor will be less than one, which means that the odds are decreased. When $\beta_{i}$ is zero, the factor equals one, which leaves the odds unchanged (Table 7).

Two models were estimated, one (Model I) in which we control for countries, where Portugal is the default, and the other (Model II), where we control for blocks of countries-with the default here being the Southern European block (comprising Italy, Portugal, Spain and Turkey). According to standard measures of goodness-of-fit, both

\footnotetext{
7 The logistic regression model is also preferred to another conventional estimation technique, discriminant analysis. According to Hosmer and Lemeshow (1989), even when assumptions required for discriminant analysis are satisfied, logistic regression still performs well.
} 


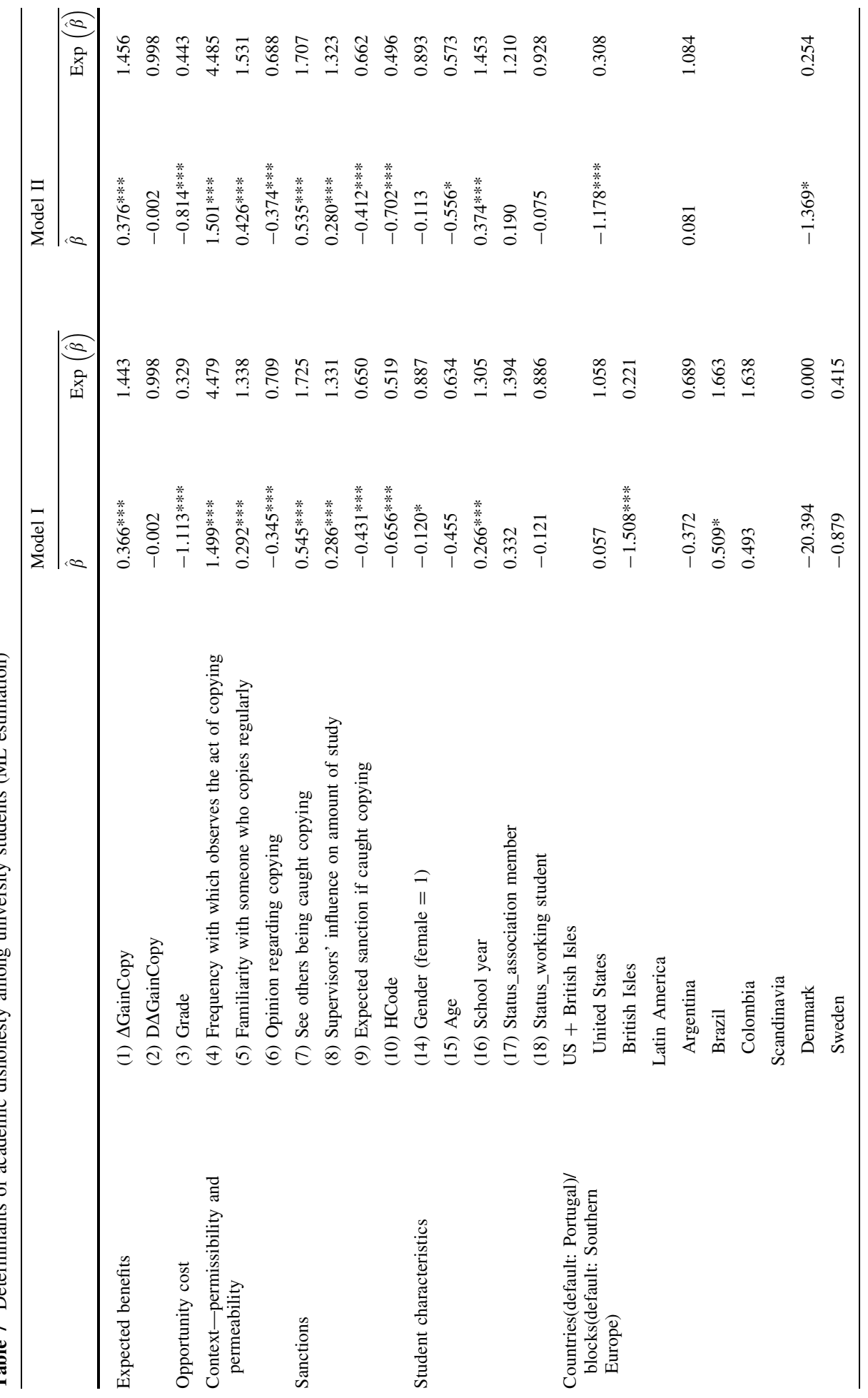




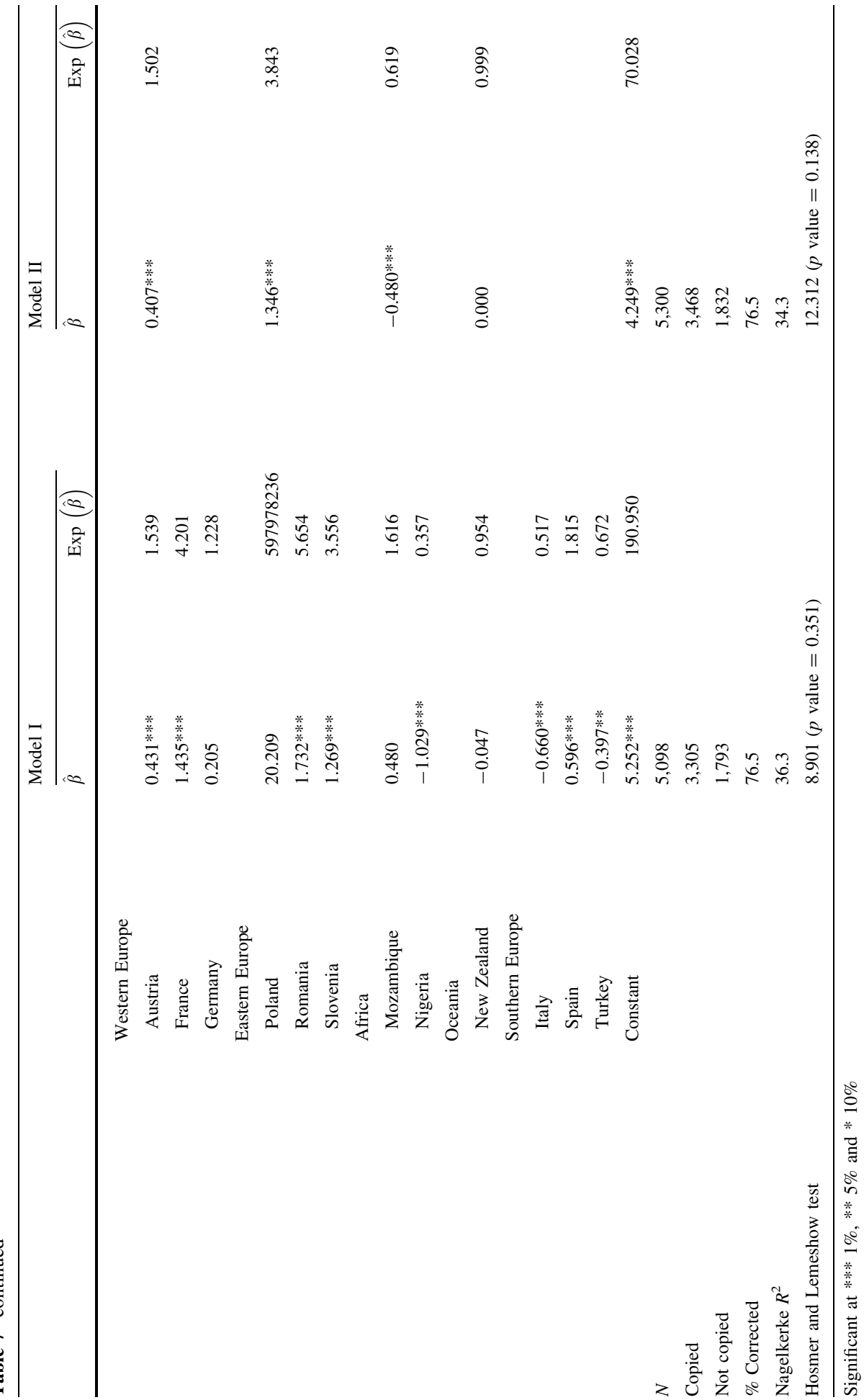


models present a reasonable quality of adjustment. In concrete, and in line with Hosmer and Lemeshow's (1989) test, where the null hypothesis highlights that the values predicted by the model are not significantly different from the observed values, given that the $p$-value is not significant for standard values, this hypothesis is not rejected, leading us to the conclusion that both models foresee reality reasonably well. Moreover, the estimated model correctly predicts around three quarters of the observed values of the dependent variable.

Controlling for either the country or the block of countries of origin does not significantly change the magnitude, the significance or the signs of the several coefficient estimates. Excluding gender and age coefficients for all the remaining variables in both models, the sign and significance of the coefficients are similar. So the models' specification and the corresponding estimates are robust.

The expected gain in terms of a higher grade when copying is successful is statistically significant and the correspondent coefficient has the expected (positive) sign, corroborating therefore Hypothesis 1 . According to our results, the odds ratio $^{8}$ changes by about 1.4 when the difference between the grade/mark students expect if they copy is positive when compared with the one they expect if they do not copying. However, nothing can be concluded concerning the absolute value of the difference between expected grades (between copying and not copying) and the odds of copying. In this line, Hypothesis 2- "The probability of copying is higher the greater the difference between the mark/grade the students say they expect if they do in fact copy, and the mark/grade they will likely obtain if no copying takes place"-cannot be corroborated by our data. The student's academic performance, assessed by his/her grade, negatively and significantly influences the propensity to commit fraud-all else constant, the higher the student's grade (i.e., the higher the opportunity cost), the lower, on average, the probability of copying.

Copying-favourable environments-proxied by the frequency with which students observe the act of copying, the familiarity with someone that copies regularly and students' opinion regarding copying - are associated with a higher propensity to commit this illegal act. The negative and significant sign of the coefficient associated to the last variable indicates that the more serious copying is, the lower the propensity of students to commit fraud. Summing up, Hypothesis 3- "In copying-favourable environments where permissibility and permeability towards copying is high, students' propensity to copy tends to be higher"-is corroborated.

Our results also show that those students who admit to studying less when there are no supervisors and/or sanctions if they are caught cheating, have a higher propensity to copy in exams. Additionally, the negative sign related to estimate of the severity of the sanctions confirms Hypothesis 4, since the higher and more serious the penalties as perceived by students, fewer are the incentives they have to perpetrate dishonest behaviours. Even though having seen other students being caught copying has a positive influence on the probability of copying, this outcome combined with the previous results, leads to the conclusion that existing sanctions have no efficient effects.

Quite significantly, the existence of 'codes of honour' or any written form which sets forth the conduct and sanctions applied in a situation where copying is detected reflects a

\footnotetext{
${ }^{8}$ Ratio of the probability of copying to the probability of not copying.
} 
lower propensity to copy, corroborating therefore Hypothesis 5- "In universities where 'codes of honour' exist, the propensity to copy among students is lower".

The school year in which students are enrolled arises here as the most (statistically) important student characteristic determining cheating behaviour. Results reveal that the closer a student is to concluding his/her degree, the higher the odds of copying. Gender is (statistically) relevant when we control for the country of the students' schools (Model I) here the negative sign of the coefficient estimate means that, ceteris paribus, female students are less prone to commit fraudulent acts-whereas age emerges as a negative relevant determinant when we control for the blocks of countries reflecting the fact that, on average, all other factors remaining constant, senior students are less likely to perpetrate illegal acts than their younger counterparts.

When controlling for a set of determinants of cheating behaviour, student status fails to be a statistically relevant variable-all else constant, having AM or WS status when compared to the 'regular' student status does not seems to result in a different attitude towards cheating.

There is significant heterogeneity in copying propensity at cross-country level. Students enrolled in schools located in countries such as Ireland and the UK (British Isles), Nigeria, Italy, and Turkey present a significantly lower propensity to commit academic fraud than students from Portuguese universities. In contrast, those enrolled in schools in Brazil, Austria, France, Romania, Slovenia, and Spain reveal substantially higher (1.5-5.6) odds of copying than those from Portugal (the default country).

The odds of copying are $75 \%,(70 \%)$, and [40\%] lower in students enrolled in schools located in Scandinavian countries, (the US and British Isles), and [Africa] when compared with their Southern European counterparts. On another level, however, students enrolled in Western and Eastern European schools reveal statistically significant higher odds (1.5-3.8, respectively) of copying than their counterparts in the Southern European schools. From these findings, we can conclude that "The propensity to copy is influenced by the countries' cultural/educational systems and social and business ethics-related factors", that is, the data seems to corroborate Hypothesis 6 .

\section{Conclusions}

Callahan (2004), author of The Cheating Culture: Why More Americans Are Doing Wrong to Get Ahead, suggested that students today feel more pressure to do well in order to get into graduate or professional schools and secure a job. Indeed, in a time of economic rationalism and high unemployment rates, the competition to gain qualifications is increasing. Passing exams, doing well in assignments, and ensuring a high ranking score in relation to fellow students-jostling for a position against competitorsis seen as a key step towards success or failure in obtaining well-paid employment in the future. Building on the widely held idea that the free market and competition are desirable attributes, such competition among student would appear to be a positive thing. According to Godfrey and Waugh (1997) this growing competition among students appears to have been responsible for a trend towards a rise in academic cheating in educational institutions.

To the best of our knowledge, excluding a recent study by Crittenden et al. (2009), no other (published) study had analyzed undergraduate cheating behaviour involving 
such a wide diversity of contexts. The empirical evaluation of the cheating phenomenon among university students has been essentially focused on the US context, covering usually only a few universities. The study by Crittenden et al. (2009), which involved 115 institutions located in 36 countries, continues to have a strong bias toward the US with 59 (51\% of the total) of the institutions analyzed located in this country and does not cover (as in our case) institutions from the Eastern European countries. Moreover, although these authors' research is quite appealing, it relies mainly on descriptive accounts of the data, not involving (as the case here) econometric data analysis. Our study involved 7,213 students enrolled in 42 universities located in 21 countries from four continents: the Americas (Argentina, Brazil, Colombia, USA), Europe (Austria, Denmark, France, Germany, Ireland, Italy, Poland, Portugal, Romania, Slovenia, Spain, Sweden, Turkey, UK), Africa (Mozambique, Nigeria) and Oceania (New Zealand), and aimed to shed new light on the magnitude of the phenomenon and its determinants across a broader range of countries.

Concerning the magnitude of cheating, the data collected revealed that there is striking heterogeneity among the countries (Table 8) and blocks of country. Indeed, the propensity to copy ranged from 5\%, the lowest, in universities located in the Scandinavian countries (Denmark and Sweden) to $88 \%$ in the universities selected in the Eastern European countries (Poland, Romania, and Slovenia).

Our results support that differences in social factors, partly reflected by the country of origin of the respondent students, are likely to comprise an important factor in explaining students' propensity to cheat. In fact, data show that (by comparison with the average), students enrolled in universities in countries such as Slovenia, Romania, Spain, Austria, France and Brazil present, regardless of context and the students' characteristics, a statistically significant higher propensity to cheat (see Fig. 10 for a schematic overview). In contrast, students from universities located in the Scandinavian countries, the British Isles, Italy, Turkey and Nigeria, reveal significantly lower trends in cheating. Thus, in line with Diekhoff et al. (1999), who detected differences and similarities in American and Japanese students copying in exams, our data revealed interesting differences between students of nationalities in terms of academic misconduct. Despite methodological differences in the data analysis, our results are strikingly in line with the descriptive research of Crittenden et al. (2009). Similarly, we saw that students enrolled in institutions located in more problematic countries with regard to corruption (cf. data from the Corruption Perception Index for 2005 and 2008 developed by Transparency International ${ }^{9}$ ) reveal, on average, a higher incidence of academic cheating.

Context emerges as a very important factor in influencing the decision to cheat. As many studies have documented (e.g., Houston 1986; Lanza-Kaduce and Klug 1986; Ward and Tittle 1993), contextual factors and the environment-peer pressure and attitudes towards academic dishonesty do stand out here as conditioning factors in the development of unlawful academic practices. Similarly to Bunn et al. (1992), we found that the likelihood of copying is directly related to observing others doing so, and the perception of the number of students who routinely copy. Students who perceive that copying is a serious crime, tend to copy less.

\footnotetext{
9 In http://www.transparency.org/.
} 
Moreover, the severity of the punishment applied if students are caught copying (i.e., the 'climate of cheating') negatively influence their propensity to cheat. Schools with honour codes tend to have lower rates of copying among students, which corroborates the findings of McCabe and Trevino (1993) and the arguments of McCabe et al. (2003).

With regard to students' characteristics, only gender and school year surfaced as statistically relevant. In line with the studies of Bushway and Nash (1977), Karebenick and Srull (1978) and Graham et al. (1994), we found significant gender differences. In fact, the data revealed that female students engaged less in cheating practices than their males counterparts. In this vein, and at least for the sample analyzed, we failed to detect a convergence in role requirements among males and females in collegiate settings. On the contrary, the results seem to follow Ward and Beck's (1990) arguments, which emphasize that sex-role socialization is thought to influence the tendency towards dishonesty through differences in internalized role requirements.

To sum up, the cheating 'culture' seems pervasive in the universities selected from Latin America, Eastern Europe, and Southern Europe. Quite differently, the phenomenon is seldom observed in universities from the Scandinavian countries. Such pervasiveness may to a large extent be explained by the opinion and attitude of students regarding academic misconduct. From the results obtained, we found that, overall, relatively few students consider cheating a serious offence. For the majority, cheating is not a problem or is a trivial problem. Interesting are the results obtained with regard to Nigeria and Argentina. Here there is a widespread awareness of the need to combat fraud and corruption. "Nigerians have identified corruption as the nation's number one problem and Nigerians are demanding that something is done about it" (IAP 2006). In fact, a recent survey in Nigeria revealed that $58 \%$ of the respondents say corruption is the nation's major problem, while $42 \%$ consider it a major problem (IAP 2006). Likewise, in Argentina, several attempts have been made in recent years to curb corruption both within society as a whole and in the education sector in particular. Arcidiacano (2005) describes how Poder Ciudadano (Transparency International's chapter on Argentina), helped the Ministry of Education to increase transparency in the pre-contract phase of a large textbook procurement. Though not all instruments were applied to their full potential, stakeholders felt that there was greater impartiality in the selection process, and that a certain level of confidence had been restored. In an in-depth reflection on Argentina's corruption, Hernandez (2004) emphasizes that “... the attempt to clean up corruption in this country, people are going to have to change the way they do politics, the way they do business, the way they run their lives. Not so much because of law or regulation but because of the recognized need to improve their standard of living". She further recognizes that with the help of NGOs like Poder Ciudadano, gradually Argentina is changing. Our data on cheating among undergraduate students reveals that, at least on this level, people are becoming more aware on the seriousness of the issue-recall that a substantial percentage of undergraduates (over 70\%) in Argentina and Nigeria consider copying in exams a serious problem that deserves attention.

The low levels of copying in the Scandinavian countries reflect to a large extent the Scandinavian philosophy regarding a corruption-free society (in Scandinavica.com Magazine 2006), defending a culture of ethicality where corruption and falseness are strictly not tolerated. In these countries rules are clear, taken seriously, and the price of being excluded from the normal circles of society is exceptionally high. 


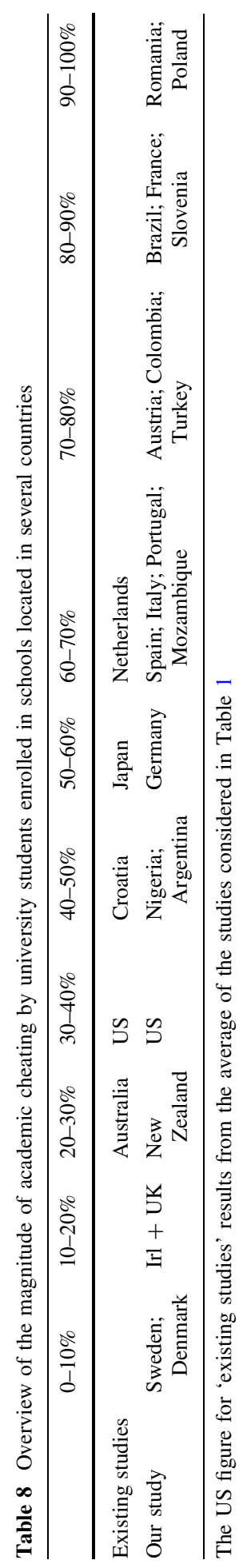




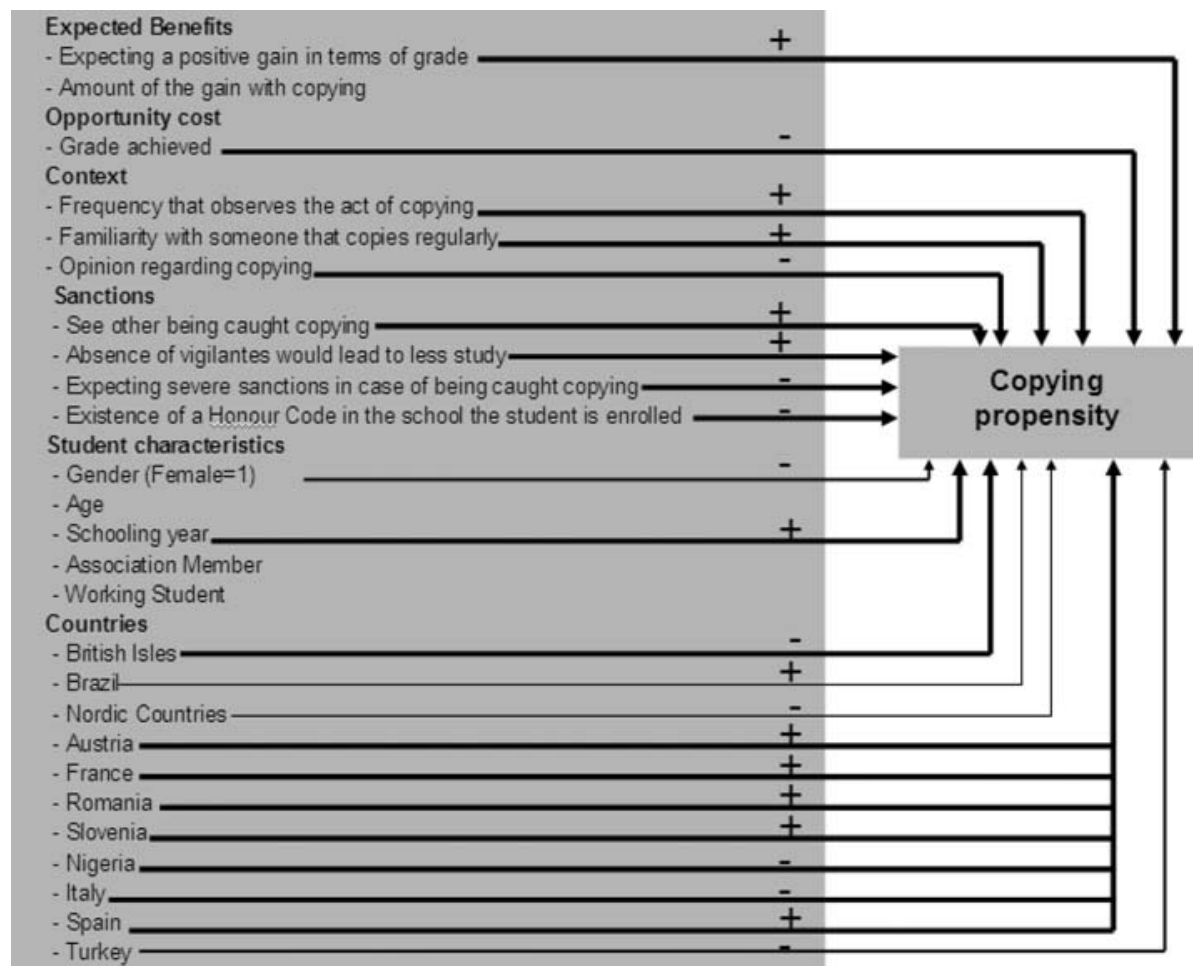

Fig. 10 Determinants of the propensity to cheat-an overview

These findings seem to indicate that curbing cheating in the classroom may not be just a matter of targeted (higher) education policies but rather a change in attitude that is transversal to society as a whole.

As in other studies which focus on academic dishonesty, our study presents some limitations that should be borne in mind when interpreting the results, and caution is advised in generalizing these findings.

A first limitation in our research, which is applicable to almost all research using survey data (Bernardi et al. 2004) has to do with the instrument applied in gathering the datastudents' self-reported academic cheating, which may be "vulnerable to a social desirability bias in responding" (Hrabak et al. 2004, p. 284). This limitation can be particularly acute when dealing with cross-country data. Self-reported estimates, however, remain the main means by which data are gathered in research on academic fraud (e.g., Bunn et al. 1992; McCabe et al. 2006; Crittenden et al. 2009), and many researchers have concluded that self-reports of cheating are generally reliable and valid (Beck and Ajzen 1991; Spiller and Crown 1995). Moreover, the fact that studies on academic cheating (e.g., Rettinger et al. 2004), which apply very different methodologies, have found that their results are convergent with those relying on self-reported techniques, and that our results are in line with other studies which involved cross-country data, such as those by Magnus et al. (2002) and Crittenden et al. (2009), support our confidence in this widely used methodology. 
Additionally, while our research includes students from 42 different universities, in 11 of the 21 countries covered, only one university was surveyed, which severely undermines the extrapolation of the results based on one (or a small number of) institution(s) in that country to the country as a whole. Even though this shortcoming also occurs in similar studies, in order to adequately perform a cross-country analysis, it would be necessary to include a higher number of institutions per country.

A third limitation has to do with the analysis of only one type of academic cheatingcopying in exams. Despite being the most widely accepted definition of cheating in academia, minimizing therefore the risk of multiple interpretations and bias dependent on context/institution/country, it would be interesting to analyze other types of unethical conduct, namely plagiarism, which according to McCuen (2008, p. 152) is "very likely more common than generally believed".

Acknowledgments We are deeply indebt to all students that responded the survey and to the following individuals (in alphabetic order) for permitting and/or implementing the questionnaire underlying this study. Directors in Portugal Antonieta Cunha Sá (UNL/University Nova of Lisboa), Artur Cristóvão (UTAD/ University of Alto Douro e Tràs-os-Montes), Fernando Almeida (Economics and Management School/ University of Minho), Joaquim Borges Gouveia (Economics, Business and Industrial Engineering Department/University of Aveiro), José Pereirinha (ISEG/University of Lisbon), José Silva Costa (FEP/University of Porto), Manuel Branco (Faculty of Economics/University of Évora), Paulo Rodrigues (Faculty of Economics/University of Algarve), Pedro Botelho (FEUC/University of Coimbra). Department Coordinators in Portugal Carlos Arriaga (Economics Department/University of Minho), Fernanda Nogueira (Bussiness Department/University of UTAD), José Caldas (Economics Department/University of UTAD). Professors/ Researchers in Portugal Ana Maria Rodrigues (University of Coimbra), António Caleiro (University of Évora), Arménio Rego (University of Aveiro), Aurora Galego (University of Évora), Carla Amado (University of Algarve), Carlos Ferreira (University of Aveiro), Carlota Quintal (University of Coimbra), Efigénio Rebelo (University of Algarve), Elisabete Félix (University of Évora), Fernando Cardoso (University of Algarve), Francisco Torres (University of Aveiro), Henrique Albergaria (University of Coimbra), Joana Costa (University of Beira Interior), João Paulo Costa (University of Coimbra), José Belbute (University of Évora), José Novais (University of Évora), Margarida Saraiva (University of Évora), Maria Graça Baptista (University of Açores), Maria João Alves (University of Coimbra), Maria João Carneiro (University of Aveiro), Maria João Thompson (University of Minho), Miguel Lebre de Freitas (University of Aveiro), Óscar Afonso (FEP/University of Porto), Patrícia Valle (University of Algarve). Other university staff Ana Paula Teixeira and Cristina Santana (University of Algarve), Sónia Fidalgo (University of Aveiro) and Leonor Dias (University of Coimbra). Professors/Researchers in other countries: Alvaro Cuervo-Cazurra (US), André Everett (New Zealand), Andreas Klossek (Germany), Anil Kumar (US), Anne-Christin Stockmeyer (Germany), Axele Giroud (UK), Beatriz Caro (Spain), Carlos Gradín (Spain), Caviola Silvia Maria (Argentina), Celestino Vaz (Mozambique), Dan Popescu (Romenia), Dilek Zamantili Nayir (Turkey), Bernd Ebert (Germany), Eduardo Moreira (Brazil), Elke Kizelmann (Austria), Frances Ruane (Ireland), Ivan Lopez (Spain), Kirsten Lange (Denmark), Lisa Fiacre (France), Luca Panaccione (Italy), Maja Makovec Brencic (Slovenia), Nazan Gunay (Turkey), Nicolae Marinescu (Romenia), Olufemi Akinwale (Nigeria), Patrycia Swierkot (Poland), Peter Forster (France), Sally Burrows (UK), Sandra Milena Santamaria (Colombia), Sanja Kocijan (Slovenia), Sourafel Girma (UK), Stefano Brusoni (Italy). A final word of appreciation to Luzia Belchior (FEP-Administrative Office) for her valuable assistance with the optical reading of the survey questionnaires, and José Mergulhão Mendonça (FEP-Computing Department) for the huge help in devising the on-line international questionnaire.

\section{Appendix: Questionnaire}

This is an anonymous questionnaire that will be analyzed in an aggregate manner and used exclusively for SCIENTIFIC purposes. Please cross $(x)$ in the selected cell. 
This is an anonymous questionnaire that will be analyzed in an aggregate manner and used exclusively for SCIENTIFIC purposes. Please cross (x) in the selected cell.

1. How frequently have you observed other students copying in exams?

$$
\text { Never } \square \text { Rarely } \square \text { Sometimes }
$$

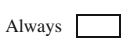

2. Have you seen another student caught copying in exams?

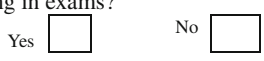

3. From your experience in multiple-choice exams, which is the percentage of students that you think might copy in that type of exams?
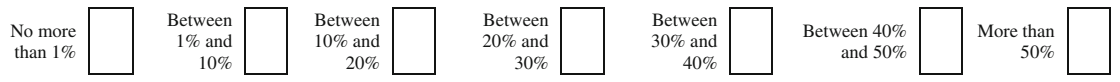

4. How often have you copied in exams?

$$
\text { Never } \square \text { Rarely } \square
$$

5. In case you have copied, were you caught?
Yes
No

Sometimes

Many times

Always

6. Do you know someone who usually copies in exams?
Yes
No

7. From the "copying" activities that you have observed, do you think that, more frequently, they are deliberate or not deliberate (i.e., do they happened occasionally or are they motivated by unexpected panic)?

$$
\text { Deliberate } \square \text { Circumstantial } \square \quad \text { Panic } \square
$$

\begin{tabular}{|c|c|c|c|c|c|c|c|c|c|c|c|}
\hline \multirow{3}{*}{$\begin{array}{l}\text { you do copy } \\
\text { you don't copy }\end{array}$} & $0 \%$ & $10 \%$ & $20 \%$ & $30 \%$ & $40 \%$ & $50 \%$ & $60 \%$ & $70 \%$ & $80 \%$ & $90 \%$ & $100 \%$ \\
\hline & & & & & & & & & & & \\
\hline & & & & & & & & & & & \\
\hline
\end{tabular}

8. In the last exam that you took, indicate the mark (rounded between $0 \%$ and $100 \%$ ) that you believe you could have obtained if

9. If there were no supervision during an exam or any sanctions for the act of copying, would you study less? If yes, how much less (in \% of the amount of study time in a normal situation)

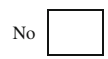

$$
\text { Yes } \begin{array}{|l|l|l|l|l|l|}
\hline 10 \% & 20 \% & 30 \% & 40 \% & 50 \% & >50 \% \\
\hline & & & & & \\
\hline
\end{array}
$$

\begin{tabular}{|c|c|c|c|c|}
\hline $\begin{array}{l}\text { Nothing more } \\
\text { than a reprimand }\end{array}$ & $\begin{array}{r}\text { Having the final } \\
\text { mark limited }\end{array}$ & $\begin{array}{r}\text { The exam be } \\
\text { annulled }\end{array}$ & $\begin{array}{l}\text { The exam be annulled and the } \\
\text { student prevented from carrying } \\
\text { out other exams in that subject } \\
\text { during the academic year }\end{array}$ & $\begin{array}{l}\text { The exam to be annulled and the } \\
\text { student be suspended for one year } \\
\text { and prevented from applying to } \\
\text { other university courses }\end{array}$ \\
\hline
\end{tabular}

10. If you were caught copying or committing some other kind of fraud in exams, what do you expect might happen to you?

11. In your opinion at your university copying in exams:

It isn't a
problem $\square \quad \begin{array}{r}\text { It is a trivial problem of } \\ \text { low importance }\end{array} \square \quad \begin{array}{r}\text { It is a problem that deserves } \\ \text { some concern }\end{array} \quad \begin{array}{r}\text { It is a very serious } \\ \text { problem }\end{array}$

12. I am now attending the [note: in case of attending two or more years chose the more advanced one]:

$$
2^{\text {nd }} \text { year } \square \quad 3^{\text {rd }} \text { year } \square \quad 4^{\text {th }} \text { year } \square
$$

13. My present student status is:

$$
\text { Normal ['Regular'] } \square \quad \text { AM[Associated Student Member] } \square \quad \text { Part-time Student } \square \quad \text { Other } \square
$$

14. Present course's average grade [simple average for the set of subjects that you had obtained approval on up-to-date]:

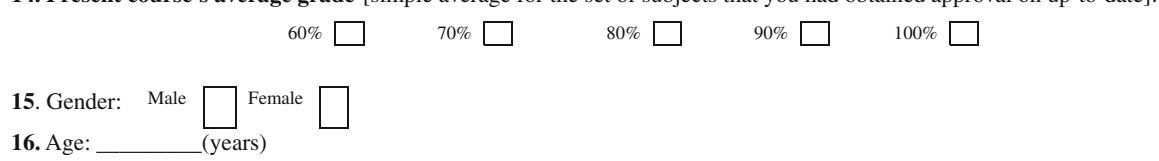

\section{References}

Antion, D. L., \& Michael, W. B. (1983). Short-term predictive validity of demographic, affective, personal, and cognitive variables in relation to two criterion measures of cheating behaviors. Educational and Psychological Measurement, 43, 467-483.

Arcidiacano, P. (2005). Argentina. Procurement: A textbook case. In B. Meier \& M. Griffin (Eds.), Stealing the future. Corruption in the classroom: Ten real world experiences, Chap. 3. Berlin, Germany: Transparency International. 
Arlow, P., \& Ulrich, T. (1985). Business ethics and business school graduates: A longitudinal study. Akron Business and Economic Review, 16, 13-17.

Baird, J. S., Jr. (1980). Current trends in college cheating. Psychology in the Schools, 17, 515-522.

Barnes, W. F. (1975). Test information: An application of the economics of search. Journal of Economic Education, 7, 28-33.

Baumhart, R. (1961). How ethical are businessmen? Harvard Business Review, 39, 6-31.

Beck, L., \& Ajzen, I. (1991). Predicting dishonest actions using the theory of planned behavior. Journal of Research in Personality, 25, 285-301.

Becker, G. S. (1968). Crime and punishment: An economic approach. Journal of Political Economy, 76, 168-217.

Bernardi, R. A., Metzger, R. L., Bruno, R. G. S., Hoogkamp, M. A. W., Reyes, L. E., \& Barnaby, G. H. (2004). Examining the decision process of students' cheating behaviour: An empirical study. Journal of Business Ethics, 50, 397-414.

Bisping, T., Patron, H., \& Roskelley, K. (2008). Modeling academic dishonesty: The role of student perceptions and misconduct type. Journal of Economic Education, 39(1), 4-21.

Bunn, D. N., Caudill, S. B., \& Gropper, D. M. (1992). Crime in the classroom: An economic analysis of undergraduate student cheating behavior. Journal of Economic Education, 23, 197-207.

Bushway, A., \& Nash, W. R. (1977). School cheating behavior. Review of Educational Research, 47, 623-632.

Cabral-Cardoso, C. (2004). Ethical misconduct in the business school: A case of plagiarism that turned bitter. Journal of Business Ethics, 49, 75-89.

Callahan, D. (2004). The cheating culture: Why more Americans are doing wrong to get ahead. Florida, US: Harcourt Books.

Campbell, W. G. (1931). Student honesty as revealed by reporting of teacher's errors in grading. School and Society, 33, 97-100.

Campbell, W. G. (1935). A comparative investigation of students under a honor system and a proctor system in the same university. Los Angeles, CA: University of Southern California Press.

Cole, B., \& Smith, D. (1996). Perceptions of business ethics: Students vs. business people. Journal of Business Ethics, 15, 889-896.

Collinson, M. (1990). Apparent rise in students' cheating has college officials worried. The Chronicle of Higher Education (January 17), A33-A35.

Crittenden, V. L., Hanna, R. C., \& Peterson, R. A. (2009). The cheating culture: A global societal phenomenon. Business Horizons, 52(4), 337-346.

Crown, D., \& Spiller, M. (1998). Learning from the literature on collegiate cheating: A review of empirical research. Journal of Business Ethics, 17, 683-700.

Daniel, L. G., Blount, K. D., \& Ferrell, C. M. (1991). Academic misconduct among teacher education students: A descriptive-correlational study. Research in Higher Education, 32, 703-724.

Davis, S. F., Grover, C. A., Becker, A. H., \& McGregor, L. N. (1992). Academic dishonesty; prevalence, determinants, techniques, and punishments. Teaching of Psychology, 19, 16-20.

DeConick, J., \& Good, D. (1989). Perceptual differences of sales practitioners and students concerning ethical behavior. Journal of Business Ethics, 8, 667-676.

Diekhoff, G. M., LaBeff, E. E., Clark, R. E., Williams, L. E., Francis, B., \& Haines, V. J. (1996). College cheating: Ten years later. Research in Higher Education, 37, 487-502.

Diekhoff, G. M., LaBeff, E. E., Shinohara, K., \& Yasukawa, H. (1999). College cheating in Japan and the United States. Research in Higher Education, 40(3), 343-353.

Fakouri, M. E. (1972). Achievement motivation and cheating. Psychological Reports, 31, 629-630.

Ford, R., \& Richardson, W. (1994). Ethical decision making: A review of the empirical literature. Journal of Business Ethics, 13(3), 205-221.

Gardner, W. M., Roper, J. T., Gonzalez, C. C., \& Simpson, R. G. (1988). Analysis of cheating on academic assignments. The Psychological Record, 38, 543-555.

Glater, J. (2006). Colleges chase as cheats shift to higher tech. The New York Times (May 18), A1-A24.

Glenn, J. (1988). Business curriculum and ethics: Student attitudes and behavior. Business and Professional Ethics Journal, 7(3\&4), 167-185.

Glenn, J., Jr., \& Van Loo, M. (1993). Business students' and practitioners' ethical decisions over time. Journal of Business Ethics, 12, 835-847.

Godfrey, J., \& Waugh, R. (1997). Students' perceptions of cheating in Australian independent schools. Education Australia, 37, 14-16.

Graham, M. A., Monday, J., O’Brien, K., \& Steffen, S. (1994). Cheating at small colleges: An examination of student and faculty attitudes and behaviors. Journal of College Student Development, 35, 255-260. 
Haines, V. J., Diekhoff, G. M., LaBeff, E. E., \& Clark, R. E. (1986). College cheating: Immaturity, lack of commitment, and the neutralizing attitude. Research in Higher Education, 25, 342-354.

Hartshorne, H., \& May, M. A. (1928). Studies in deceit. New York: MacMillan.

Hernandez, S. (2004). Combating corruption in Argentina. www.duke.edu/web/las/Funding/hernandez paper.pdf. Accessed May 2006.

Hollon, C. J., \& Ulrich, T. A. (1979). Personal business ethics: Managers vs managers-to-be. Southern Business Review, 5, 17-22.

Hosmer, D., \& Lemeshow, S. (1989). Applied logistic regression. New York: Wiley.

Houston, J. P. (1983). College classroom cheating, threat, sex and prior performance. College Student Journal, 16, 229-235.

Houston, J. P. (1986). Classroom answer copying: Roles of acquaintanship and free versus assigned seating. Journal of Educational Psychology, 78, 230-232.

Houston, J. P., \& Ziff, T. (1976). Effects of success and failure of cheating behavior. Journal of Educational Psychology, 68, 371-376.

Hrabak, M., Vujaklija, A., Vodopivec, I., Hren, D., Marusic, M., \& Marusic, A. (2004). Academic misconduct among medical students in a postcommunist country. Medical Education, 38(3), 276-285.

IAP-Independent Advocacy Project. (2006). Corruption is Nigeria's major problem. http://www.indadvocacy-project.org/Press\%20Statements.htm.

Karebenick, S. A., \& Srull, T. K. (1978). Effects of personality and situational variation in locus of control on cheating: Determinance of the congruence effect. Journal of Personality, 46, 72-95.

Kerkvliet, J. (1994). Cheating by economics students: A comparison of survey results. Journal of Economic Education, 25(2), 121-133.

Kerkvliet, J., \& Sigmun, C. L. (1999). Can we control cheating in the classroom? Journal of Economic Education, 30(4), 331-351.

Kidwell, L. (2001). Student honor codes as a tool for teaching professional ethics. Journal of Business Ethics, 29, 45-49.

Lanza-Kaduce, L., \& Klug, M. (1986). Learning to cheat: The interaction of moral-development and social learning theories. Deviant Behavior, 7, 243-259.

Lawson, R. (2004). "Is classroom cheating related to business students' propensity to cheat in the "real world"? Journal of Business Ethics, 49, 189-199.

Leming, J. S. (1980). Cheating behavior, subject variables, and components of the internal-external scale under high and low risk conditions. Journal of Educational Research, 74, 83-87.

Lord, A. T., \& Melvin, K. B. (1997). The attitudes of accounting students, faculty, and employers toward cheating. In L. Ponemon (Ed.), Research on accounting ethics (Vol. 3, pp. 1-20). New York: JAI Press Inc.

Magner, D. (1989). Students urge graduate business schools to emphasize ethical behavior and require courses in standards. The Chronicle of Higher Education, 354(29), A31-A32.

Magnus, J. R., Polterovich, V. M., Danilov, D. L., \& Savvateev, A. V. (2002). Tolerance of cheating: An analysis across countries. Journal of Economic Education, 33, 125-135.

Maramark, S., \& Maline, M. (1993). Academic dishonesty among college students. Issues in education. Washington, DC: Department of Education, Office of Research.

May, K. M., \& Loyd, B. H. (1993). Academic dishonesty: The honor system and students' attitudes. Journal of College Student Development, 34, 125-129.

McCabe, D. L. (2005). CAI research. Center for academic integrity. http://academicintegrity.org/cai_ research.asp. Accessed Apr 2006.

McCabe, D. L., Butterfield, K. D., \& Trevino, L. K. (2003). Faculty and academic integrity: The influence of current honor codes and past honor code experiences. Research in Higher Education, 44(3), 367-385.

McCabe, D., Butterfield, K. D., \& Trevino, L. K. (2006). Academic dishonesty in graduate business programs: Prevalence, causes, and proposed action. Academy of Management Learning \& Education, 5(3), 294-305.

McCabe, D. L., \& Trevino, L. K. (1993). Honor codes and other contextual influences. Journal of Higher Education, 64, 522-538.

McCabe, D. L., \& Trevino, L. K. (1997). Individual and contextual influences on academic dishonesty: A multicampus investigation. Research in Higher Education, 38(3), 379-396.

McCuen, R. H. (2008). The plagiarism decision process: The role of pressure and rationalization. IEEE Transactions on Education, 51, 152-156.

Meier, B., \& Griffin, M. (Eds.). (2005). Stealing the future. Corruption in the classroom: Ten real world experiences. Berlin, Germany: Transparency International.

Michaels, J. W., \& Miethe, T. D. (1989). Applying theories of deviance to academic cheating. Social Science Quarterly, 70, 870-885. 
Millham, J. (1974). Two components of the need for approval score and their relationship to cheating following success and failure. Journal of Research in Personality, 8, 378-392.

Nazario, S. L. (1990). Schoolteachers say it's wrongheaded to try to teach students what's right. The Wall Street Journal, B1, B8.

Newstrom, J., \& Ruch, W. (1976). The ethics of business students: Preparation for a career. AACSB Bulletin, 12(3), 21-29.

Nonis, S., \& Swift, C. (2001). An examination of the relationship between academic dishonesty and workplace dishonesty: A multicampus investigation. Journal of Education for Business, 77(2), 69-77.

Nowell, C., \& Laufer, D. (1997). Undergraduate student cheating in the fields of business and economics. Journal of Economic Education, 28, 3-12.

Pavela, G., \& McCabe, D. L. (1993). The surprising return of honor codes. Planning for Higher Education, 21(4), 27-32.

Pulvers, K., \& Diekhoff, G. M. (1999). The relationship between academic dishonesty and college classroom environment. Research in Higher Education, 40(4), 487-498.

Rettinger, D. A., Jordan, A. E., \& Peschiera, F. (2004). Evaluating the motivation of other students to cheat: A vignette experiment. Research in Higher Education, 45(8), 873-890.

Rocha, M. F., \& Teixeira, A. A. C. (2005a). Crime without punishment: An update review of the determinants of cheating among university students. FEP working papers no. 191, Oct 2005.

Rocha, M. F., \& Teixeira, A. A. C. (2005b). College cheating in Portugal: Results from a large scale survey. FEP working papers no. 197, Dec 2005.

Sheard, J., \& Dick, M. (2003). Influences on cheating practice of graduate students in IT courses: What are the factors? ACM SIGCSE Bulletin, 35(3), 45-49.

Sheard, J., Markham, S., \& Dick, M. (2003). Investigating differences in cheating behaviours of IT undergraduate and graduate students: The maturity and motivation factors. Higher Education Research and Development, 22(1), 91-108.

Sims, R. (1993). The relation between academic dishonesty and unethical business practices. Journal of Education for Business, 68, 207-211.

Smyth, L. S., Davis, J. R., \& Kroncke, C. O. (2009). Students' perceptions of business ethics: Using cheating as a surrogate for business situations. Journal of Education for Business, 84(4), 229-239.

Spiller, S., \& Crown, D. F. (1995). Changes over time in academic dishonesty at the collegiate level. Psychological Reports, 76(3), 763-768.

Stevens, G. E. (1984). Ethical inclinations of tomorrow's citizens: Actions speak louder? Journal of Business Education, 59, 147-152.

Stickman (2004). Thailand, the future. Stickman weekly 19th September 2004. http://www.stickman bangkok.com/Weekly/weekly176.html.

Teixeira, A. A. C., \& Rocha, M. F. (2006). College cheating in Austria, Portugal, Romania and Spain: A comparative analysis. Research in Comparative and International Education, 1(3), 198-209.

TI. (2006). Corruption perception index 2005. Berlin, Germany: Transparency International.

Tibbets, S. G. (1999). Differences between women and men regarding decisions to commit test cheating. Research in Higher Education, 40(3), 323-342.

Ward, D. A., \& Beck, W. L. (1990). Gender and dishonesty. Journal of Social Psychology, 130, 333-339.

Ward, D. A., \& Tittle, C. R. (1993). Deterrence or labeling: The effect of informal sanctions. Deviant Behavior: An Interdisciplinary Journal, 14, 43-64.

Whitley, B. E. (1998). Factors associated with cheating among college students: A review. Research in Higher Education, 39(3), 235-274.

Wood, J., Longenecker, J., McKinney, J., \& Moore, C. (1988). Ethical attitude of students and business professionals: A study of moral reasoning. Journal of Business Ethics, 7, 249-257. 